Review Article

\title{
Lippia javanica (Burm.f.) Spreng.: Traditional and Commercial Uses and Phytochemical and Pharmacological Significance in the African and Indian Subcontinent
}

\author{
Alfred Maroyi \\ Department of Botany, University of Fort Hare, Private Bag X1314, Alice 5700, South Africa \\ Correspondence should be addressed to Alfred Maroyi; amaroyi@ufh.ac.za
}

Received 5 September 2016; Revised 25 October 2016; Accepted 20 November 2016; Published 1 January 2017

Academic Editor: Rainer W. Bussmann

Copyright (C) 2017 Alfred Maroyi. This is an open access article distributed under the Creative Commons Attribution License, which permits unrestricted use, distribution, and reproduction in any medium, provided the original work is properly cited.

\begin{abstract}
Lippia javanica occurs naturally in central, eastern, and southern Africa and has also been recorded in the tropical Indian subcontinent. The potential of L. javanica as herbal or recreational tea and herbal medicine and its associated phytochemistry and biological properties are reviewed. The extensive literature survey revealed that L. javanica is used as herbal tea and has ethnomedicinal applications such as in colds, cough, fever, malaria, wounds, diarrhoea, chest pains, bronchitis, and asthma. Multiple classes of phytochemicals including volatile and nonvolatile secondary metabolites such as alkaloids, amino acids, flavonoids, iridoids, and triterpenes as well as several minerals have been identified from $L$. javanica. Scientific studies on $L$. javanica indicate that it has a wide range of pharmacological activities which include anticancer, antiamoebic, antidiabetic, antimalarial, antimicrobial, antioxidant, antiplasmodial, and pesticidal effects. Although many of the traditional uses of L. javanica have been validated by phytochemical and pharmacological studies, there are still some gaps where current knowledge could be improved. Lippia javanica is popular as both herbal and recreational tea, but there is need for more precise studies to evaluate the safety and clinical value of its main active crude and pure compounds and to clarify their mechanisms of action.
\end{abstract}

\section{Introduction}

Lippia javanica (Burm.f.) Spreng. (Verbenaceae) (Figure 1(a)) has a long history of traditional uses in tropical Africa as indigenous herbal tea or tisane (Figure 1(b)), refreshing beverage, or food additive based on its perceived health and medicinal properties. Lippia javanica is rich in volatile oil, particularly caryophyllene, carvone, ipsenone, ipsdienone, limonene, linalool, myrcene, myrcenone, ocimenone, $p$-cymene, piperitenone, sabinene, and tagetenone [1-5]. Research by Viljoen et al. [3] revealed that the essential oil profiles of $L$. javanica are characterized by inter- and intraspecies variations because they are produced by different metabolic pathways. Using cluster analysis, Viljoen et al. [3] identified five chemotypes of L. javanica in South Africa and Swaziland, myrcenone-rich type (36-62\%), carvone-rich type (61-73\%), piperitenone-rich type (32-48\%), ipsdienonerich type $(42-61 \%)$, and linalool-rich type $(>65 \%)$. The relative proportion of the chemical constituents of $L$. javanica essential oil is important as this determines the biological properties of the species chemotypes.

Lippia javanica belongs to the Verbena or vervain family (Verbenaceae) comprising approximately 32 genera and 840 species [97]. The genus Lippia L. is named after Augustin Lippi (1678-1701), an Italian botanist and natural historian who was killed in Ethiopia at the age of 23 [98]. Phylogenetic relationships within family Verbenaceae demonstrated that genus Lippia and other closely related genera, namely, Aloysia Paláu, Lantana L., and Phyla Lour., are not monophyletic [97]. The boundaries separating these four genera are historically weak, with many taxonomic researchers including species belonging to Aloysia, Lantana, and Phyla in the genus Lippia [99]. Lippia and Lantana genera are the most difficult to separate, as species of these two genera show similarities in their inflorescences that are spicate, often subcapitate during anthesis and elongating in fruit and pedunculated 


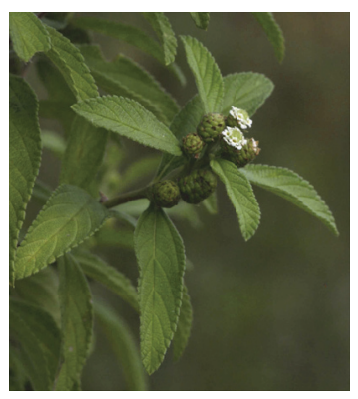

(a)

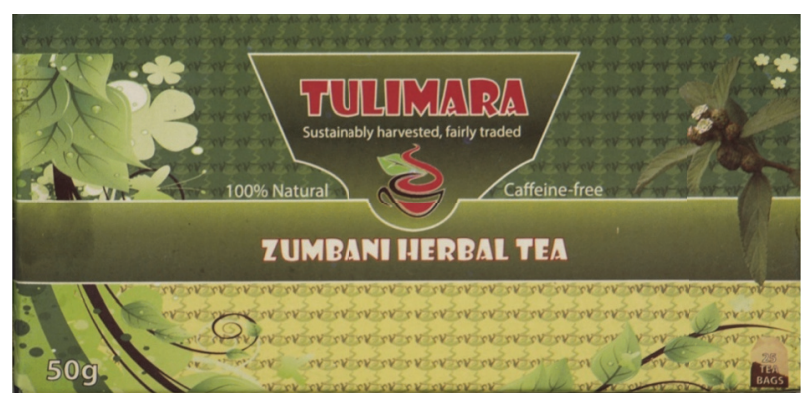

(b)

FIGURE 1: (a) Lippia javanica (Burm.f.) Spreng. flowers and leaves (photo: BT Wursten) and (b) L. javanica herbal tea traded as Zumbani in Zimbabwe (http://specialityfoods.co.zw/product/zumbani/).

[98]. According to de Campos et al. [100], the genus Lippia comprises about 200 species of herbs, shrubs, and small trees distributed throughout south and central America and tropical Africa. Only 15 Lippia species have been recorded in tropical Africa [101]. The specific name "javanica" was given by the Dutch Botanist Nicolaas Laurens Burman (17341793) in 1768, who mistakenly thought that the type specimen was collected in Java, Indonesia [102]. He placed the species in the genus Verbena, and the German botanist Sprengel (1766-1833) transferred Burman's name to the genus Lippia in 1825 [103]. Lippia javanica is morphologically similar to $L$. scaberrima Sond. but is much taller and its bracts are shorter than the flowers (Figure 1(a)), while L. scaberrima has many stems arising from ground level and is usually less than 0.5 metres high, and its bracts are not longer than the flowers [104].

Lippia javanica is an erect woody perennial herb or shrub of up to $4.5 \mathrm{~m}$ tall, with strong aromatic leaves which give off a lemon-like fragrance when crushed [105]. Stems are brownish, usually erect or spreading with short stiff tubercle-based whitish hairs and small glands, and branched with inflorescences in nearly all axils. Leaves are opposite or in whorls of 3 , blades lanceolate to oblong and densely pubescent, rounded and then cuneate at the base, and crenate-serrate or closely serrulate on the margins except near the leaf base [106]. Flowers occur in conical or oblong spikes, purple or dull-reddish in fruit, dark brownish on drying [101, 106]. The flowers are sessile or with short peduncles, lower bracts of spikes ovate and upper bracts smaller, pubescent, glandular, and densely spreading [101]. The calyx is 2-lobed, half as long as the corolla, pubescent, and densely spreading. The corolla is white, yellowish-white to greenish (Figure 1(a)), usually with a yellow throat, glandular and pubescent outside in the upper half, tube narrowly funnel-shaped from a narrow base $[101,106]$. Anthers are sulphur-yellow and nutlets are brown and half ovoid $[101,106]$.

Lippia javanica occurs naturally in central, eastern, and southern Africa (Figure 2) and has also been recorded in the tropical Indian subcontinent $[12,13,23,39,47,61]$. In subSaharan Africa, the species is native to Angola, Botswana, Central African Republic, Democratic Republic of Congo, Ethiopia, Kenya, Malawi, Mozambique, South Africa, Swaziland, Tanzania, Uganda, Zambia, Zanzibar, and Zimbabwe.

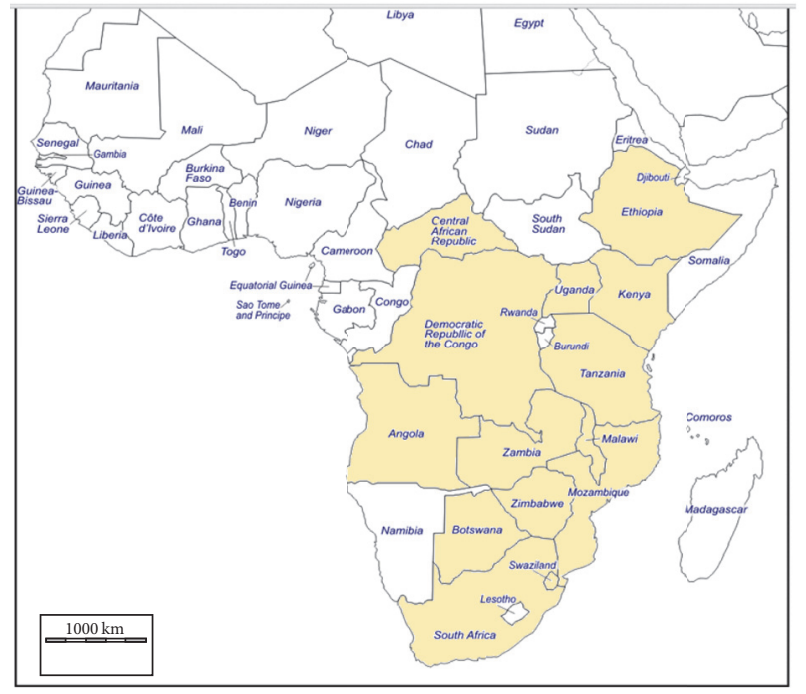

FIGURE 2: Lippia javanica naturally occurs in central, eastern, and southern Africa.

Lippia javanica has been recorded in low to high altitude $(0-2350 \mathrm{~m}$ above sea level) woodlands and wooded grasslands, scrub bushland, and grassy rocky kopjes, in riverine vegetation, and on margins of dambos and swampy ground, sometimes on termite mounds, in montane grasslands, and on evergreen forest margins, also in disturbed ground beside roads, forest clearings, plantations, and cultivated land and becoming a weed in derived rangelands $[101,106]$. This shows that the plant is highly adaptable to a wide range of climatic, soil, and vegetation conditions.

\section{Traditional Uses of Lippia javanica}

Lippia javanica is used for a wide variety of traditional uses (Table 1). Based on literature, the most important traditional applications include its uses as herbal tea and ethnomedicinal applications for (in descending order of importance) colds, cough, fever or malaria, wounds, repelling mosquitos, diarrhoea, chest pains, bronchitis, and asthma (Figure 3 ). These different uses are discussed in the following seven sections: 


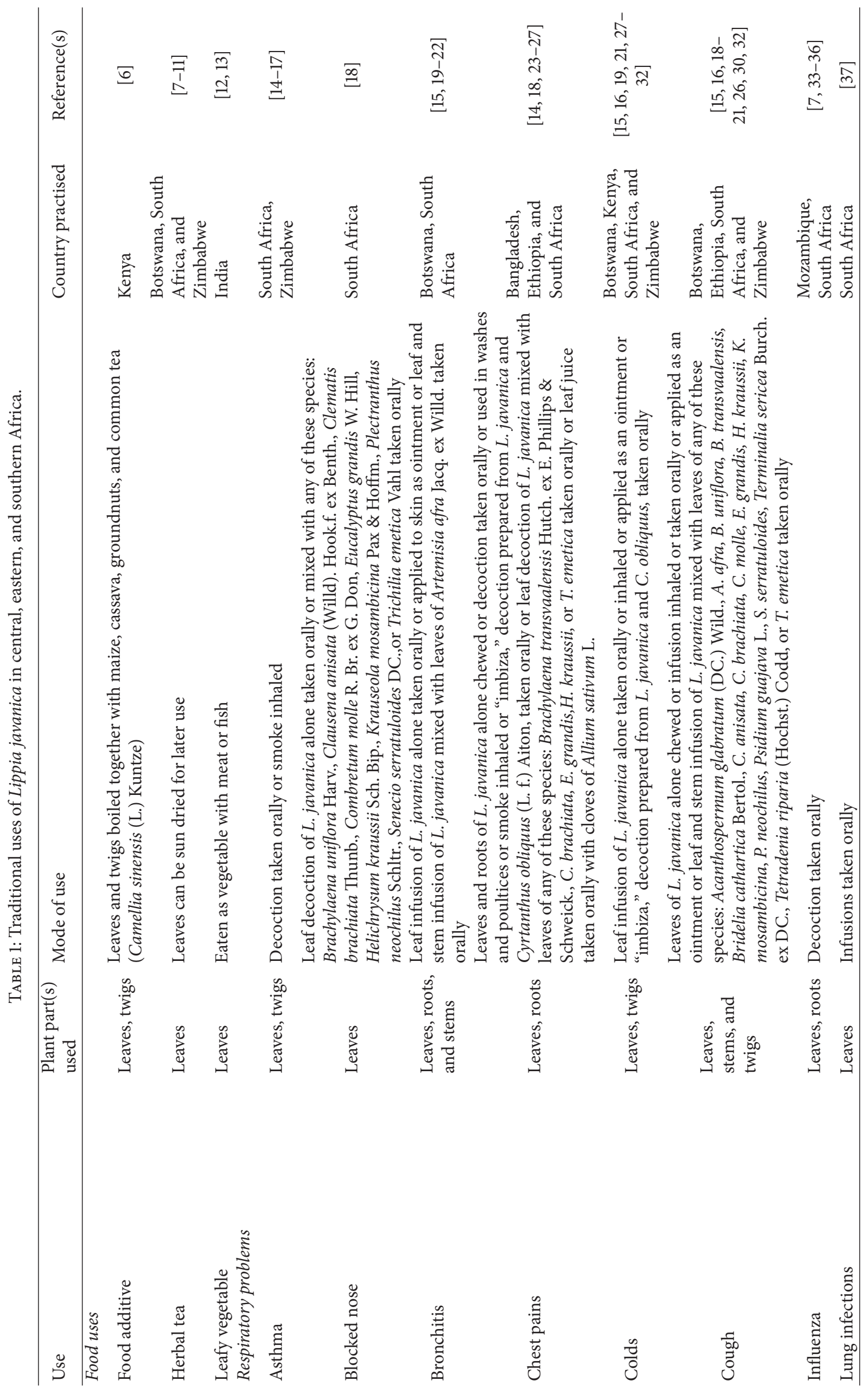




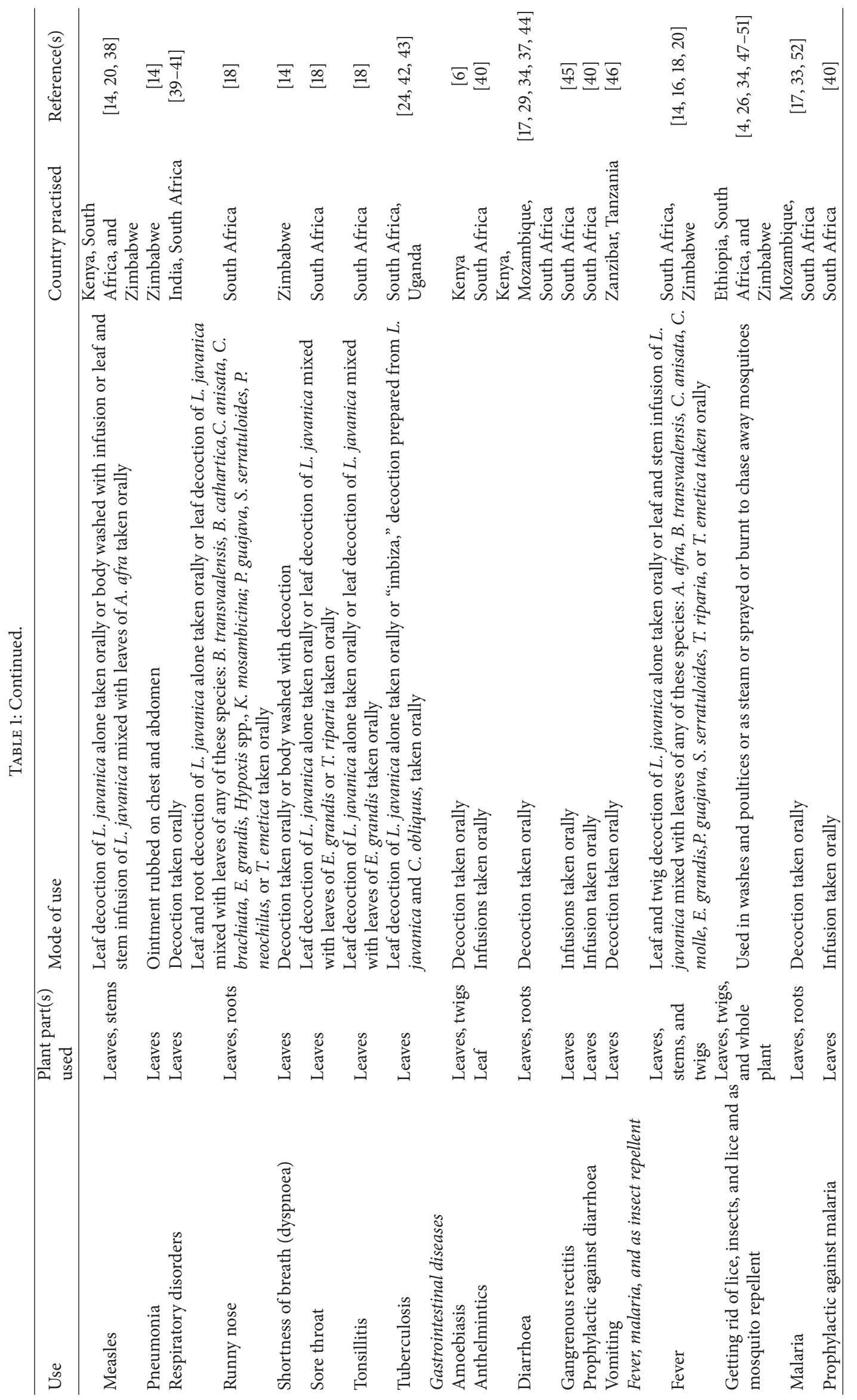




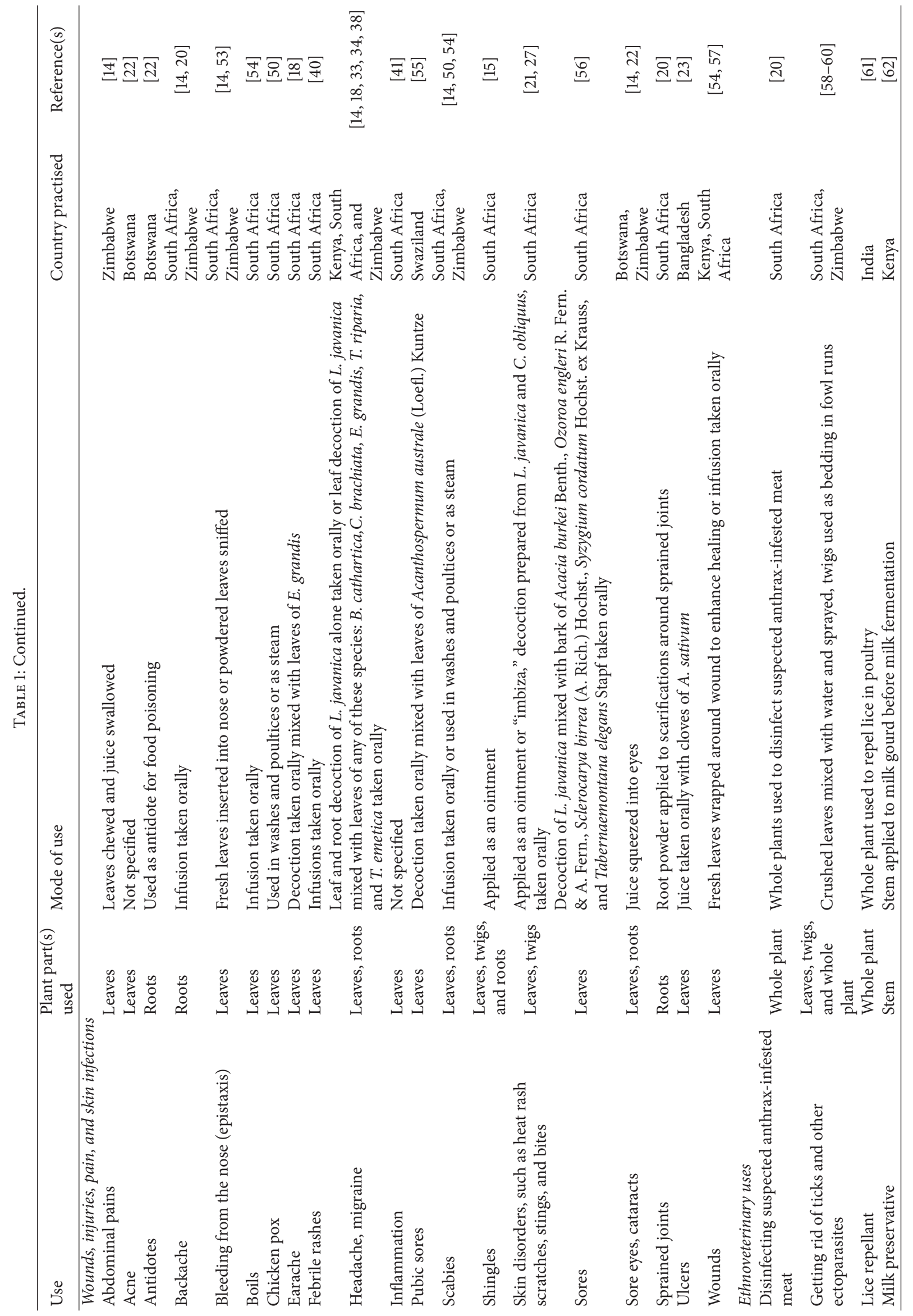




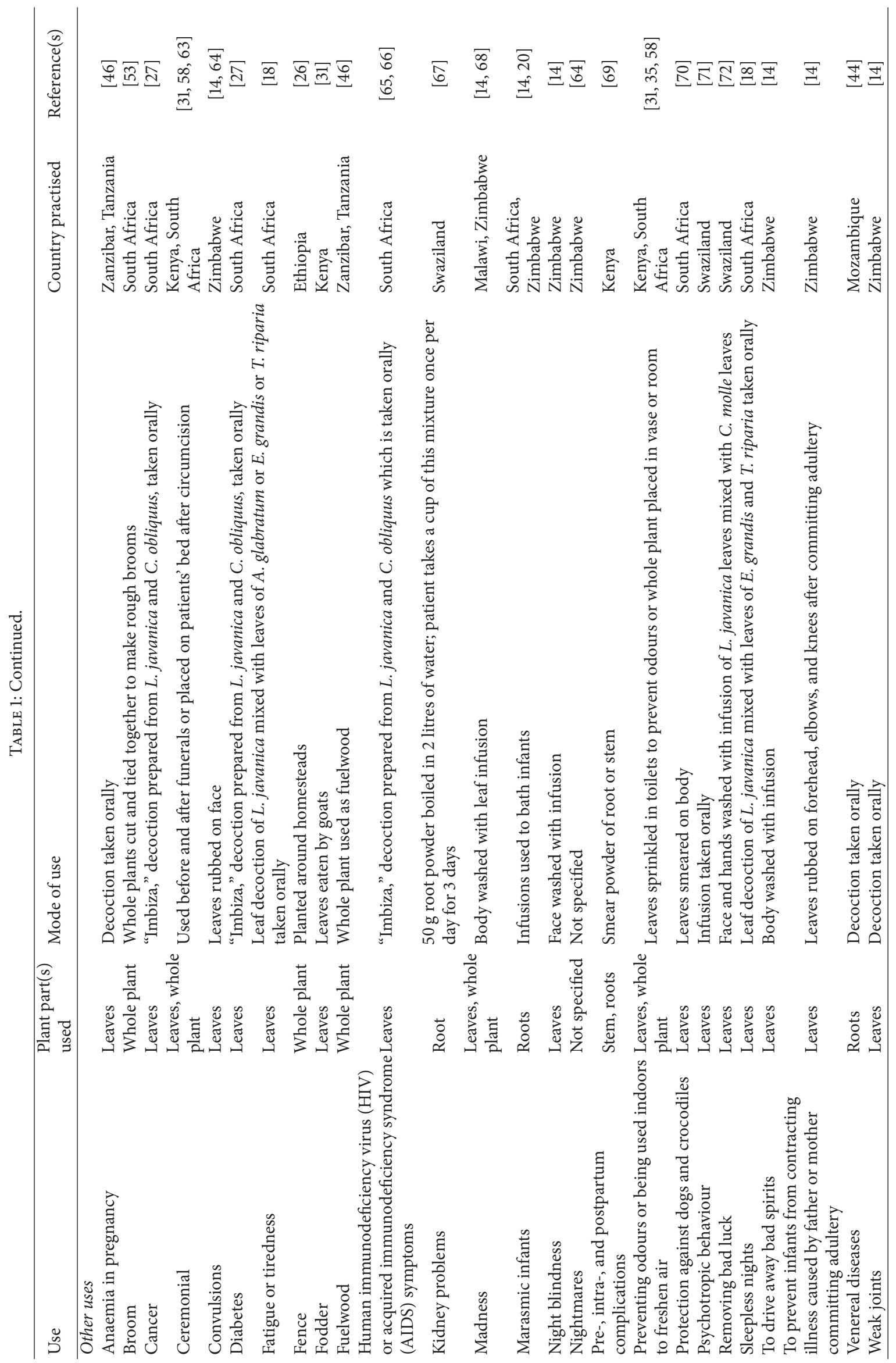




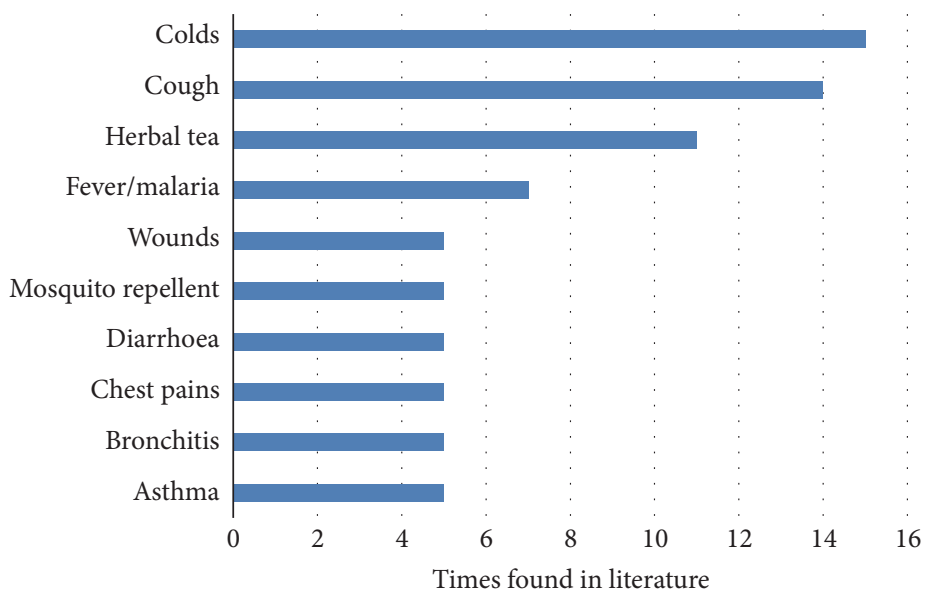

FIGURE 3: Main ethnobotanical applications of Lippia javanica in central, eastern, and southern Africa. An ethnobotanical use is counted only once per publication.

Food Uses; Respiratory Problems; Gastrointestinal Diseases; Fever, Malaria, and Insect Repellent; Wounds, Injuries, Pain, and Skin Infections; Ethnoveterinary Uses; and Other Uses.

2.1. Food Uses. Leaves and twigs of Lippia javanica are used as food additives in Kenya [6] and leafy vegetable in India $[12,13]$. Lippia javanica is popular as herbal tea, particularly in Botswana, South Africa, and Zimbabwe [7-11]. Lippia javanica herbal tea is prepared by steeping fresh or dried leaves, stems, or twigs in boiling water and letting them stand for two to five minutes to release flavour, with or without milk and sugar added according to taste. A stronger brew, known as a decoction, is prepared by boiling fresh or dried leaves, stems, or twigs for more than five minutes. The herbal tea prepared from L. javanica leaves, stems, or twigs has a lemon or vanilla aroma and is often used as a common tea (i.e., C. sinensis) substitute or a few leaves, stems, or twigs are added to $C$. sinensis to provide a lemon or vanilla aroma. According to Sõukand and Kalle [87], herbal tea or tisane is an English term used to denote a decoction or infusion made of herbs for medicinal purposes. When L. javanica is used as medicinal herbal tea, it is consumed for a limited number of days to treat a specific condition like asthma in Zimbabwe [14], bronchitis in South Africa [19], chest pains in Zimbabwe and South Africa [14, 24], colds in Kenya, South Africa, and Zimbabwe [19, 20, 28-30], cough in South Africa and Zimbabwe [19, 20, 30, 53], and other diseases (see Table 1). From literature, it seems L. javanica herbal tea evolved over the years from medicinal tea decoctions or infusions to nonmedicinal uses, where the herbal tea is now drunk for recreation and enjoyment. According to Shikanga et al. [7], L. javanica tea is appreciated throughout its distributional range as a general health tonic and also because it is naturally caffeine-free and has a calming and relaxing effect. Research done by other workers, for example, Manenzhe et al. [2], Shikanga et al. [7], Parrant [8], Olivier et al. [81], Motlhanka and Makhabu [9], and Bhebhe et al. $[10,11]$, revealed that L. javanica is a popular recreational tea in southern Africa, consumed on a daily basis within a food context, while medicinal infusions or tisanes of $L$. javanica are taken for a specific medical purpose. During the past 20 years, the use of herbal teas has increased globally [107] because of their functional properties and consumer interest in the health promoting properties of such beverages [108]. The other advantage associated with $L$. javanica usage is that the leaves can be sun-dried and later boiled in water and drunk as herbal tea [9].

Most of L. javanica used as herbal tea in rural and periurban communities in central, eastern, and southern Africa is still collected from the wild, although smallscale cultivation has become necessary as it is marketed as herbal tea in Botswana under the brand name "Mosukudu" or "Mosukujane" [109] and in Zimbabwe as "Zumbani" (Figure 1(b)). Although considerable quantities of L. javanica are sold in local markets in Botswana and Zimbabwe and also traded on the Internet, there is no data on present production levels, traded volumes, values, and export figures in these two countries. Research by Whiteside [110] showed that sales of L. javanica tea bags generated an income of R20300.00 (US\$5718) during 1994/1995 in Botswana. There is increased demand for L. javanica herbal tea especially in the light of growing health consciousness worldwide, with the estimated potential demand for the species and its products around 100 tonnes per year on the local market and 1000 tonnes per year on the export market (http://bioinnovation.org/work/fever-tea-tree/). Considering the rapid growth of the herbal tea industry worldwide and the increasing demand for L. javanica products, there is need for the improvement of $L$. javanica products as well as development of new products. Therefore, L. javanica has potential to make the transition from limited local use to commercial and international product. Lippia javanica has been identified as one of the few plant species that should be integrated in the domestication process in farming systems in subSaharan Africa to support medicinal, nutritional, and income security of local communities $[107,111]$. According to Van Wyk [111], L. javanica is of commercial value as herbal tea and health drinks. Therefore, commercialization of $L$. javanica is 
unlikely to be viable if the product is sorely harvested from the wild. In the same line commercialization of $L$. javanica might be more worthy if other products other than tea are derived from the plant.

2.2. Respiratory Problems. The different parts of L. javanica, for example, the leaves and twigs, are used for the treatment of asthma, coughs, colds, influenza, pneumonia, tuberculosis, and bronchial problems in Bangladesh, Botswana, Ethiopia, Kenya, South Africa, and Zimbabwe [14-16, 19, 20, 23, 25, 26, $28-32,53,112$ ]. In Bangladesh, leaf infusion of L. javanica is taken orally mixed with 3-4 pieces of cloves of A. sativum, 2-3 times daily as remedy for chest pains [23]. In Ethiopia, leaves of $L$. javanica are chewed with butter as remedy for chest pains and cough [26]. In India, L. javanica leaf decoction is taken orally as remedy for respiratory disorders [39]. In Kenya, leaves are sniffed [31] or half glass of hot leaf infusion is taken orally three times a day $[28,29]$ as remedy for colds and cough. Research done by Davids et al. [19] in South Africa revealed that about $50 \mathrm{~g}$ of leaves is added to a cup of boiling water to produce an infusion which is taken orally as remedy for coughs, colds, and bronchial problems or the infusion is applied to the skin or mixed with Vaseline to make an ointment. In South Africa, leaf or twig decoction is taken orally for asthma, colds, and cough [16, 53], leaves are used in washes and poultices for chest pains [25], and leaves are boiled for 5 minutes and one cup of extract is taken orally thrice a day for chest pains and tuberculosis [24, 42]. According to York [18], two handfuls of L. javanica leaves are boiled in two litres of water and patient is steamed once or twice a day to treat coughs, chest pain, headaches, fever, chills, a sore throat, or a blocked nose. This decoction can also be taken orally by drinking half a cup daily [18]. Alternatively, a handful of $L$. javanica roots or leaves are mixed with a handful leaves of A. glabratum or B. transvaalensis or $B$. uniflora or B. cathartica or C. anisata or C. brachiata or C. molle or E. grandis or H. kraussii or Hypoxis spp. or K. mosambicina or P. neochilus or P. guajava or S. serratuloides or $T$. sericea or $T$. riparia or $T$. emetica to treat blocked nose, chest pain, cough, earache, fatigue, fever, influenza, headache, runny nose, sleepless nights, sore throat, tiredness, and tonsillitis [18]. Leaf and stem infusion of L. javanica are taken orally together with $A$. afra by the Zulu people in South Africa as remedy for bronchial ailments, colds, and cough [20]. "Imbiza," a popular herbal decoction prepared from $L$. javanica and C. obliquus, is used by the Zulu people in South Africa as herbal tonic and an immune booster and also for the treatment of cancer, chest pains, colds, diabetes, HIV or AIDS symptoms, skin infections, and tuberculosis [27]. In some communities in South Africa, L. javanica leaf or root infusion is taken orally as remedy for influenza and malaria [33] and respiratory disorders [40, 41]. In Zimbabwe, leaf or root decoction is taken orally or smoke of burnt leaves and roots is inhaled as remedy for chest pains [14] and leaf and twigs are boiled in water and infusion is taken orally as remedy for colds and cough [30]. According to Gelfand et al. [14], Shona people in Zimbabwe rub leaf ointment of $L$. javanica on the chest and abdomen as remedy for pneumonia and leaf decoction is taken orally and body washed with leaf decoction as remedy for shortness of breath or dyspnoea. In South Africa, a leaf and stem infusion of $L$. javanica are taken orally together with leaves of $A$. afra as remedy for measles [20].

Based on literature, inhalation of smoke from L. javanica appears to be a popular remedy for asthma, chest pains, colds, and chronic coughs in Botswana, South Africa, and Zimbabwe [14, 15, 20, 32]. In Botswana, L. javanica leaf infusion vapour is inhaled as remedy for colds and cough [32]. In South Africa, for example, leaves and twigs are burned and smoke is inhaled as remedy for asthma and cough [15] or steam from leaf infusions is inhaled or hot leaf infusions are taken orally against colds and cough [20]. In Zimbabwe, smoke of burnt leaves and roots is inhaled as remedy for chest pains [14].

2.3. Gastrointestinal Diseases. The leaf and root decoction or infusions of L. javanica are used as remedies of the digestive system diseases such as cholera, diarrhoea, and dysentery. For example, in Mozambique, root decoction is taken orally as remedy for a type of diarrhoea commonly known as "chinhamucaca" which is characterized by milky diarrhoea accompanied by vomiting in children [44]. Leaf decoction is used as herbal medicine for diarrhoea in Kenya [113]. In South Africa, the leaves of L. javanica are crushed and mixed with cold or hot water and the mixture is then sieved and a quarter of a cup $(75 \mathrm{~mL})$ is taken twice a day until diarrhoea subsides [34]. The Venda people in South Africa use leaf infusions as prophylactic against diarrhoea [40]. Research done by Palgrave et al. [37] in South Africa revealed that tea infusions of the L. javanica leaves are used as remedies for HIV/AIDS opportunistic infections such as lung infections and diarrhoea. Previous research in Mozambique [114], South Africa [115], and Zimbabwe [116] showed that gastrointestinal disorders, particularly cholera, diarrhoea, and dysentery are among human diseases often treated with herbal medicines. For those patients diagnosed as having intestinal worms in Venda, South Africa, a leaf infusion of L. javanica leaves is used as an anthelmintic [40]. Therefore, these findings illustrate that herbal medicines including L. javanica can play an important role in basic health care of local communities through treatment and management of cholera, diarrhoea, and dysentery.

2.4. Fever, Malaria, and Insect Repellent. Traditionally, L. javanica is commonly used to treat fever and malaria and repel insects throughout its distributional range $[4,14,16$, 17, 33-35, 40, 48-50, 58-60]. In South Africa, a decoction of fresh or air dried leaves is used to wash or steam body parts infested with lice [50]. In India, the whole plant is used to repel lice in poultry [61]. In South Africa and Zimbabwe, whole plant or leaves are burnt to repel mosquitoes [4, 34, 35, 48, 49, 58]. In South Africa and Zimbabwe, L. javanica is widely used to get rid of ticks and other ectoparasites; for example, ticks are sprayed with crushed leaves mixed with water or twigs are used as bedding in fowl runs [58-60]. Leaf and twig decoction of L. javanica are taken orally as remedy for fever [16]. The Venda people in South Africa use leaf infusions of L. javanica as prophylactic against malaria 
[40]. In Zimbabwe, leaf decoction is taken orally as remedy for fever [14].

Lippia javanica is also cultivated on a commercial scale by a rural community in Giyani, the Limpopo province, South Africa, for the production of mosquito-repellent candles [117]. Clinical studies using human volunteers showed that $L$. javanica repels no less than $95 \%$ of mosquitos, whereas most mosquito repellents repel only $42 \%$ of them [118]. Based on these findings, the Council for Scientific and Industrial Research (CSIR), South Africa, signed a benefit sharing agreement with traditional healers allowing for the commercial cultivation of $L$. javanica aimed at establishing an indigenous oil industry for rural development and largescale production of antimosquito candles and other insect repellents. The mosquito repellent is registered as a patent under the Fertilisers, Farm Feeds and Stock Remedies Act (Act 36 of 1947) as a pest repellent [119]. These findings and the establishment of a large-scale production of antimosquito candles and other insect repellents strengthen the view that $L$. javanica is a potential source of antipesticidal agents and to some extent validate the traditional use of the plant species for insect pest control. Pesticidal plants such as $L$. javanica are increasingly being used as alternatives where synthetic products are unaffordable or are not available or are ineffective. A number of studies have indicated that the use of $L$. javanica as a pesticide is a long-standing tradition passed down from generation to generation [120].

2.5. Wounds, Injuries, Pain, and Skin Infections. Lippia javanica is used as remedy for a variety of skin infections and injuries in Kenya, South Africa, Swaziland, and Zimbabwe. In South Africa, leaf infusions are used to treat skin disorders, such as boils, chicken pox, febrile rashes, heat rashes, measles, scabies, scratches, and stings [20, 21, 40, 50, 54]. In Kenya, about $50 \mathrm{~g}$ of fresh leaves is wrapped around a fresh wound to enhance healing [57] and, in South Africa, leaf infusions are taken orally as remedy for wounds [54]. In South Africa, powder from burnt roots of $L$. javanica is applied to scarifications made around sprained joints to facilitate healing [20]. In Kenya and Zimbabwe, leaf infusion is taken orally to treat measles or a patient is washed with leaf infusion $[14,38]$. The Zulu people in South Africa take a mixture of chopped handful leaves of $L$. javanica with the same amount of bark of A. burkei, O. engleri, S. birrea, S. cordatum, and T. elegans boiled in two litres of water as an enema for the treatment of sores [56]. In Swaziland, about $30 \mathrm{~g}$ of L. javanica leaves and similar amount of Acanthospermum australe Kuntze are boiled in 5 litres of water and decoction is taken as remedy for sores [55]. In Zimbabwe, root ashes of $L$. javanica mixed with fat are applied to the skin of a patient with scabies [14]. Wound healing is a process which involves distinct overlapping phases of coagulation, inflammation, proliferation, and tissue remodelling [121]. The same authors argued that a set of complex biochemical events takes place in a closely orchestrated cascade to repair the wound and any errors in the wound healing process can lead to delayed healing or formation of hypertrophic scars. Abubakar [122] argued that colonization of wounds by opportunistic microorganisms usually delays the wound healing process and/or may lead to infectious condition. Therefore, application of L. javanica on wounds and skin infections leads to disinfection, debridement, and provision of a suitable environment for aiding the wound healing process. Lippia javanica has potential for therapeutic use in wound and skin diseases management, but there is need for research on the safety, phytochemistry, and biological properties of the species.

2.6. Ethnoveterinary Uses. The leaves, stems, twigs, and whole plants of L. javanica are used as ethnoveterinary medicine in India, Kenya, South Africa, and Zimbabwe. The Xhosa people in the Eastern Cape province, South Africa, use $L$. javanica leaves for the disinfection of meat that has been infected with anthrax [20]. In Kenya, the stem of L. javanica is used to preserve milk by applying it to the gourd before milk fermentation [62]. In India, whole plants are used as lice repellants while, in South Africa and Zimbabwe, crushed leaves mixed with water are used to get rid of ticks and twigs are used as bedding in fowl runs to get rid of ectoparasites [58-60].

2.7. Other Uses. Lippia javanica is used as a good luck charm, to treat persons experiencing bad dreams, to ward off evil spirits, to protect one from lightening, and to protect the home (Table 1). In Zimbabwe, L. javanica leaves are prepared as an infusion to treat persons experiencing nightmares [64]. In both South Africa and Zimbabwe, evil spirits are cleansed by washing the body of an affected person by leaf infusion of $L$. javanica $[14,123]$. In Swaziland, $50 \mathrm{~g}$ leaves of $L$. javanica and C. molle are ground into a powder and 5 litres of water is added and face and hands are washed to remove bad luck when exposed to a corpse [71]. In South Africa, the whole plant is placed on a patient's bed after the circumcision ceremony [58], to prevent odours and freshen surrounding air. A mixture of L. javanica leaves and roots is used to clean tools and hands before and after funerals, the stems and leaves are used as brooms to sweep grave sites, and the entire plant is also used when coming from the mortuary to remove bad spirits $[58,124]$. The corpse is washed with L. javanica infusion after death to prevent odours forming or if the corpse has an odour, women place pieces of $L$. javanica in the nostrils of the corpse and sweep the room with twigs where the person was sleeping [58]. In KwaZulu Natal, South Africa, if the meat started to smell it will be boiled with $L$. javanica leaves to take away the smell [58]. The Xhosa people in the Eastern Cape province, South Africa, use $L$. javanica leaves for the disinfection of meat that has been infected with anthrax [20]. In KwaZulu Natal, South Africa, leaves are sprinkled in toilets to prevent odours [58]. Leaves of $L$. javanica are sprinkled in houses for pleasant smell in the Limpopo province, South Africa [35], and Kenya [31]. In KwaZulu Natal, South Africa, it is believed that a person can repel snakes by placing a small stem with leaves on his or her head [58]. In Malawi, Swaziland, and Zimbabwe, people showing sign of mental disorder, madness, or hysterical outbursts are required to wash their bodies with leaf infusions $[14,67,68,71]$. 
TABLE 2: Nutritional composition of Lippia javanica leaves.

\begin{tabular}{|c|c|c|}
\hline Caloric and nutritional composition & Values & Reference \\
\hline Ash & $1.60 \pm 0.001 \mathrm{~g}$ & {$[13]$} \\
\hline Calorific value & $50.64 \pm 5.63 \mathrm{kcal}$ & {$[13]$} \\
\hline Crude fat & $0.16 \pm 0.001 \mathrm{~g}$ & {$[13]$} \\
\hline Crude fibre & $2.63 \pm 0.002 \mathrm{~g}$ & [13] \\
\hline Crude protein & $1.22 \pm 0.0004 \mathrm{~g}$ & {$[13]$} \\
\hline Dry matter & $15.46 \pm 1.40 \mathrm{~g}$ & [13] \\
\hline Moisture & $90.44 \pm 0.26 \mathrm{~g}$ & [13] \\
\hline Total carbohydrate & $6.55 \pm 0.26 \mathrm{~g}$ & {$[13]$} \\
\hline Vitamin C & $22.42 \pm 0.001 \mathrm{mg}$ & {$[13]$} \\
\hline $\mathrm{Ca}$ & $2856-9225 \mu \mathrm{g} \mathrm{g}^{-1}$ & {$[27]$} \\
\hline $\mathrm{Mg}$ & $1598-5619 \mu \mathrm{g} \mathrm{g}^{-1}$ & [27] \\
\hline $\mathrm{Fe}$ & $75-750 \mu \mathrm{g} \mathrm{g}^{-1}$ & [27] \\
\hline $\mathrm{Mn}$ & $40.1 \pm 1.16 \mu \mathrm{g} \mathrm{g}^{-1}$ & {$[27]$} \\
\hline $\mathrm{Zn}$ & $15.6-27.3 \mu \mathrm{g} \mathrm{g}^{-1}$ & [27] \\
\hline $\mathrm{Cu}$ & $3.0-8.5 \mu \mathrm{g} \mathrm{g}^{-1}$ & {$[27]$} \\
\hline $\mathrm{Cr}$ & $0-2.7 \mu \mathrm{gg}^{-1}$ & {$[27]$} \\
\hline $\mathrm{Se}$ & $2.57 \pm 0.19 \mu \mathrm{g} \mathrm{g}^{-1}$ & {$[27]$} \\
\hline $\mathrm{Pb}$ & $0.38-1.19 \mu \mathrm{g} \mathrm{g}^{-1}$ & [27] \\
\hline $\mathrm{Cd}$ & $0.53 \pm 0.05 \mu \mathrm{g} \mathrm{g}^{-1}$ & {$[27]$} \\
\hline Co & $0.19 \pm 0.01 \mu \mathrm{g} \mathrm{g}^{-1}$ & {$[27]$} \\
\hline
\end{tabular}

\section{Phytochemical Constituents and Nutritional Composition of Lippia javanica}

Multiple classes of phytochemicals including volatile and nonvolatile secondary metabolites, such as alkaloids, amino acids, flavonoids, iridoids, and triterpenes as well as several minerals, have been identified from $L$. javanica $[1-5,7,13,27$, $73,78,81,83-86,88-94,120,123,125-127]$. Leaves, flowers, and twigs of $L$. javanica have a wide variety of the so-called classic nutrients, such as minerals, carbohydrates, proteins, fats, and vitamins (Table 2). Lippia javanica leaves are a good source of minerals such as cadmium, calcium, chromium, cobalt, copper, iron, magnesium, manganese, selenium, and zinc [27]. These authors assessed the levels of the elements in $L$. javanica leaves and found the elements to be in the decreasing order of $\mathrm{Ca}>\mathrm{Mg}>\mathrm{Fe}>\mathrm{Zn}>\mathrm{Mn}>\mathrm{Cu}>\mathrm{Se}>$ $\mathrm{Cr}>\mathrm{Pb}>\mathrm{Co}>\mathrm{Cd}$ for total concentrations and $\mathrm{Ca}>\mathrm{Mg}$ $>\mathrm{Fe}>\mathrm{Zn}>\mathrm{Cu}>\mathrm{Cr}>\mathrm{Pb}$ for water extractable forms. These results corroborate an observation made by Sedaghathoor et al. [128] that $\mathrm{Ca}$ and $\mathrm{Mg}$ are among the most abundant elements in tea plants. These mineral elements are important in human nutrition since $L$. javanica is used as herbal tea and food additive (Table 1). Calcium, magnesium, iron, manganese, and zinc play a major role in activating some enzymes and regulating many responses of cells to stimuli [129]. Some of the mineral elements identified from $L$. javanica leaves are required by the human body for repair of worn out cell tissues and strong bones and teeth and building of red blood cells and other related tissues. Therefore, since $L$. javanica has appreciable concentrations of mineral elements such as calcium, magnesium, iron, manganese, and zinc
(Table 2) which are essential for enzyme metabolism, these mineral elements could enhance the nutritional and curative properties of the species.

Bhebhe et al. [10] determined the total phenolic and tannin content and radical scavenging activities of $L$. javanica, comparing it with Aspalathus linearis (Burm.f.) R. Dahlgren $\left(\right.$ Rooibos $^{\mathrm{TM}}$ ), a commercial South African herbal tea, and other popular herbal teas in Zimbabwe (Table 3). Adansonia digitata L., Fadogia ancylantha Schweinf., Ficus sycomorus L., and Myrothamnus flabellifolius Welw. are indigenous herbal teas consumed in Zimbabwe. The tannin content of $L$. javanica is very low when compared to A. linearis (Rooibos) (Table 3). Lippia javanica has higher radical scavenging activity than A. linearis (Table 3 ) which is probably due to higher total phenolic content in comparison to A. linearis which is a popular herbal tea consumed by $10 \%$ of the global herbal tea market [10]. In another study, Bhebhe et al. [11] determined and compared the effect of several solvents, namely, hot water, $50 \%$ methanol, ethanol, $50 \%$ ethanol, acetone, $50 \%$ acetone, and ethyl acetate, on phenolic composition and free radical scavenging activity in common black tea, C. sinensis, and five other well-known herbal teas including L. javanica. In all the seven solvents used, $L$. javanica had higher total phenolic content than C. sinensis implying that $L$. javanica is competitive to the black tea in terms of phenolic content. Shikanga et al. [7] found leaf extracts of L. javanica to have higher phenolic content of $14.8 \mathrm{mg} / \mathrm{g}$ gallic acid equivalent of dry weight than flowers $(9.9 \mathrm{mg} / \mathrm{g})$ and twigs $(8.3 \mathrm{mg} / \mathrm{g})$. Phenolic compounds found in plants are known to play an important role as antioxidants in exhibiting the medicinal properties such as antibiotic, anti-inflammatory, anticancer, and antiallergic properties [10, 66, 130, 131].

The compounds isolated from L. javanica are documented and listed in Appendix A and their structures are presented in Appendix B. Simple phenolic compounds and caffeic acid and its derivatives are some of the compounds that have been identified in $L$. javanica and examples include coumarin 1, 3,4-dihydroxy- $\beta$-phenylethoxy-O- $\left[4^{\prime \prime}\right.$ $\beta$-caffeoyl- $\alpha$-rhamnopyranosyl-( $\left(1^{\prime \prime \prime}, 3^{\prime \prime}\right)$-O- $\beta$-glucopyranoside], commonly referred to as verbascoside 2 , and 3,4dihydroxy- $\beta$-phenylethoxy-O-[ $6^{\prime \prime}-\beta$-caffeoyl- $\alpha$-rhamnopyranosyl- $\left(1^{\prime \prime \prime}, 3^{\prime \prime}\right)$-O- $\beta$-glucopyranoside] commonly referred to as isoverbascoside 3 isolated by Olivier et al. [81] from the aerial parts of the species. Nonvolatile diterpenes, known as iridoid-glycosides, have also been isolated from $L$. javanica by Rimpler and Sauerbier [82] represented by theveside-Na 4 and theveridoside 5. Mujovo et al. [83] isolated a long chain alkane "4-ethylnonacosane" 6 and four flavanones apigenin 7 , cirsimaritin 8, 6-methoxyluteolin $4^{\prime}$-methyl ether 9, and 6-methoxyluteolin $3^{\prime}, 4^{\prime}, 7$-trimethyl ether $\mathbf{1 0}$ from ethanolic extracts of $L$. javanica leaves. Madzimure et al. [120] identified an array of phenolic glycosides and flavonoids which include crassifolioside 11, luteolin 12, diosmetin 13, chrysoeriol 14, tricin 15, isothymusin 16, eupatorin 17, 5-dimethyl noboletin 18, genkwanin 19, salvigenin 20, and an alkaloid xanthine 22. Ludere et al. [84] isolated lippialactone $\mathbf{2 1}$ from the ethyl acetate extract of aerial parts of L. javanica. Neidlein and Staehle [85] and Dlamini [86] isolated 19 amino acids, compounds 23 to 
TABLE 3: Total phenolic content (TPC) as gallic acid equivalents (GAE) and tannin content as leucocyanidin equivalents (LE) and free radical scavenging activity (FRSA) of herbal tea extracts (after Bhebhe et al. [10]).

\begin{tabular}{lccc}
\hline Plant species & TPC g GAE/100 g & Tannin content of LE/100 g & Percentage FRSA $^{\text {IC }}$ g0 $/ \mathrm{mL}$ \\
\hline Lippia javanica & $12.46 \pm 4.31$ & $0.12 \pm 0.01$ & $83.77 \pm 0.8$ \\
Aspalathus linearis & $6.69 \pm 0.83$ & $0.94 \pm 0.04$ & $67.27 \pm 0.25$ \\
Adansonia digitata & $0.79 \pm 0.28$ & $1.69 \pm 0.01$ & $43.07 \pm 1.0$ \\
Fadogia ancylantha & $2.88 \pm 0.48$ & $0.20 \pm 0.12$ & $70.0 \pm 0.40$ \\
Ficus sycamores & $14.02 \pm 0.01$ & $1.98 \pm 0.12$ & $86.13 \pm 0.85$ \\
Myrothamnus flabellifolius & $4.75 \pm 0.33$ & $1.04 \pm 0.01$ & $80.93 \pm 0.75$ \\
\hline
\end{tabular}

41 in Appendix A, from L. javanica. At least 131 different classes of essential oil compounds (compounds 42-172 in Appendices A and B) have been isolated from L. javanica by several researchers $[3-5,83,85,86,88-94,123]$. Hutchings and van Staden [96] isolated a toxic triterpenoid saponin, icterogenin 173, from $L$. javanica leaves. These different classes of essential oil compounds have been associated with various therapeutic activities such as anaesthetic, analgesic, anti-inflammatory, antimicrobial, cardiovascular, decongestant, digestive, expectorant, hepatoprotective, and sedative activities as well as stimulant of nervous system and tonifying effects [132]. Meanwhile flavonoids possess several pharmacological properties including antibacterial, anticancer, anti-inflammatory, antioxidant, antiviral, and hepatoprotective effects [133] which play important roles in human health. Flavonoid such as apigenin 7 is reported to possess antibacterial [134] and hepatoprotective [135] properties. Apigenin 7 and luteolin $\mathbf{1 2}$ are reported to possess anti-inflammatory and analgesic effects [133], affecting the function of enzyme systems involved in the generation of inflammatory processes, especially tyrosine and serinethreonine protein kinases $[136,137]$. It has also been reported that apigenin 7 prevents HIV-1 activation via a novel mechanism that involves inhibition of viral transcription [138] and luteolin 12 demonstrated synergistic effects with another flavonoid kaempferol against herpes simplex virus [133]. Kamiya [139] documented the importance of essential amino acids such as lysine, valine, isoleucine, and histidine in terms of the risks to health if they are deficient. The author also documented their biological effects which include muscle protein maintenance, potentiation of immune function, tissue repair acceleration after burn or trauma, protecting liver from toxic agents, lowering blood pressure, modulating cholesterol metabolism, and stimulating insulin or growth hormone secretion. Therefore, $L$. javanica leaves and other plant parts which have shown to be rich in flavonoid and polyphenolic compounds, amino acids, and essential oil could play an important role in the treatment and management of diseases such as hypertension and inflammation listed in Table 1 .

\section{Pharmacological Activities}

Scientific studies on $L$. javanica indicate that it has a wide range of pharmacological activities (Table 4), which include anticancer [140], antidiabetic [141], antimalarial [4, 49, 142], antimicrobial $[2,3,7,17,73-75,77,83,84,126,143]$, antioxidant $[7,10,11,75,77,125]$, antiplasmodial $[2,79$, $80,84,144,145]$, and pesticidal effects $[1,2,59,95,120$, 146-150] and cytotoxicity $[2,73,79,120]$ activities. Table 4 summarizes some of the pharmacological studies undertaken on $L$. javanica extracts aimed at evaluating some of the ethnomedicinal uses of the species documented throughout its distributional range (see Table 1). Some of the listed pharmacological activities may not relate directly to the documented ethnomedicinal uses of the species but may provide some insight into the species' potential therapeutic value and bioactive properties and application.

4.1. Anticancer Activity. Fouche et al. [140] reported anticancer activity of dichloromethane root extract of $L$. javanica against three human cells, exhibiting TGI value of $1.82 \mu \mathrm{g} / \mathrm{mL}$ for breast MDA-MB-435, $1.86 \mu \mathrm{g} / \mathrm{mL}$ for breast MDA-N, and $2.09 \mu \mathrm{g} / \mathrm{mL}$ for melanoma MALME-3M. Based on literature, a couple of terpenoid compounds that have been isolated from $L$. javanica are known to have antitumor properties. For example, linalool $\mathbf{1 2 0}$ is known to have antitumor activity which plays a protective role against hepatotoxicity and the compound has anti-inflammatory activities as well [151]. Research by Yang et al. [152] showed limonene 92 to have inhibitory effect on pancreatic and mammary tumors. Another terpenoid compound, $\alpha$-pinene 44, is known to inhibit translocation of NF- $\kappa \mathrm{B}$ or $\mathrm{p} 65$ protein into nuclei of LPS-stimulated THP-1 cells [153]. These findings serve as a scientific validation for the use of $L$. javanica as a component of a herbal concoction known in KwaZulu Natal province as "imbiza," prepared by mixing L. javanica with C. obliquus as herbal medicine for cancer [27].

4.2. Antidiabetic Activity. Arika et al. [141] determined the in vivo antidiabetic activity of aqueous leaf extracts of $L$. javanica in white male alloxan-induced albino mice. The aqueous leaf extracts of $L$. javanica at all dose levels significantly lowered the blood glucose levels in both oral and intraperitoneal routes. The antidiabetic effect of $L$. javanica could have been due to the observed presence of flavonoids. The polyhydroxylated flavonol enhances lipogenesis and glucose uptake in the adipocytes and flavanoids have demonstrated insulinmimetic properties as the compound is known to be effective at controlling blood sugar levels. These findings 


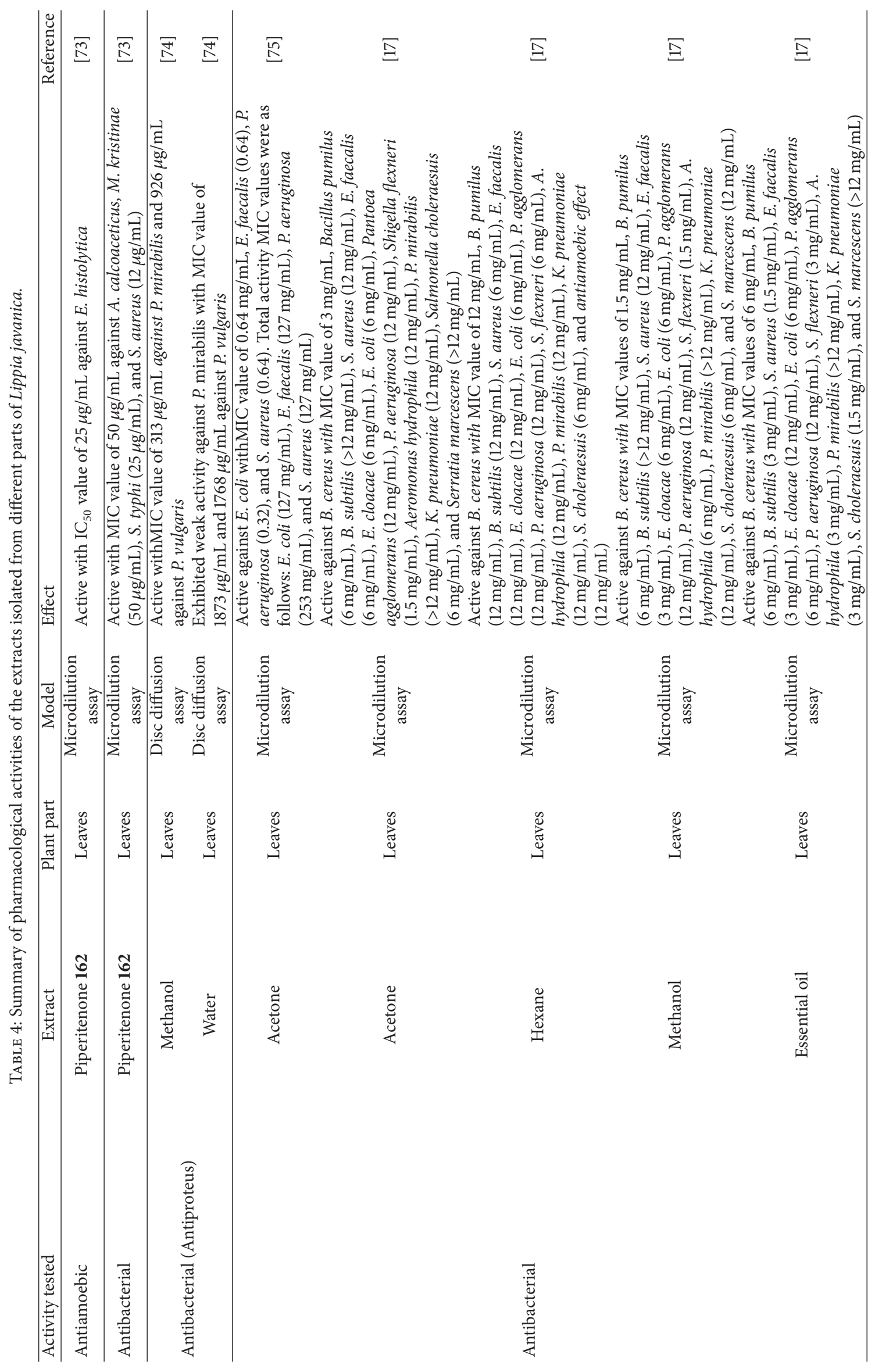




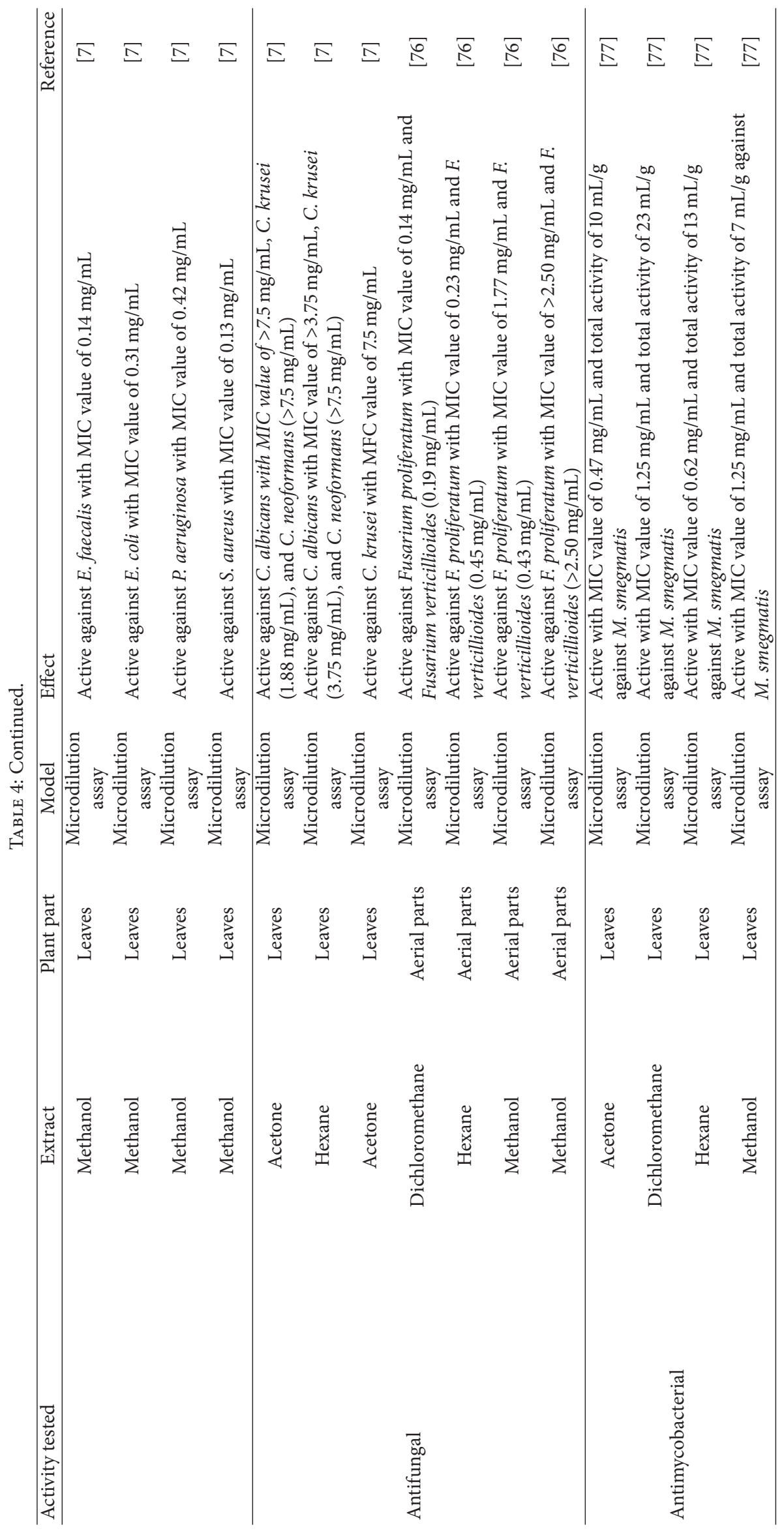




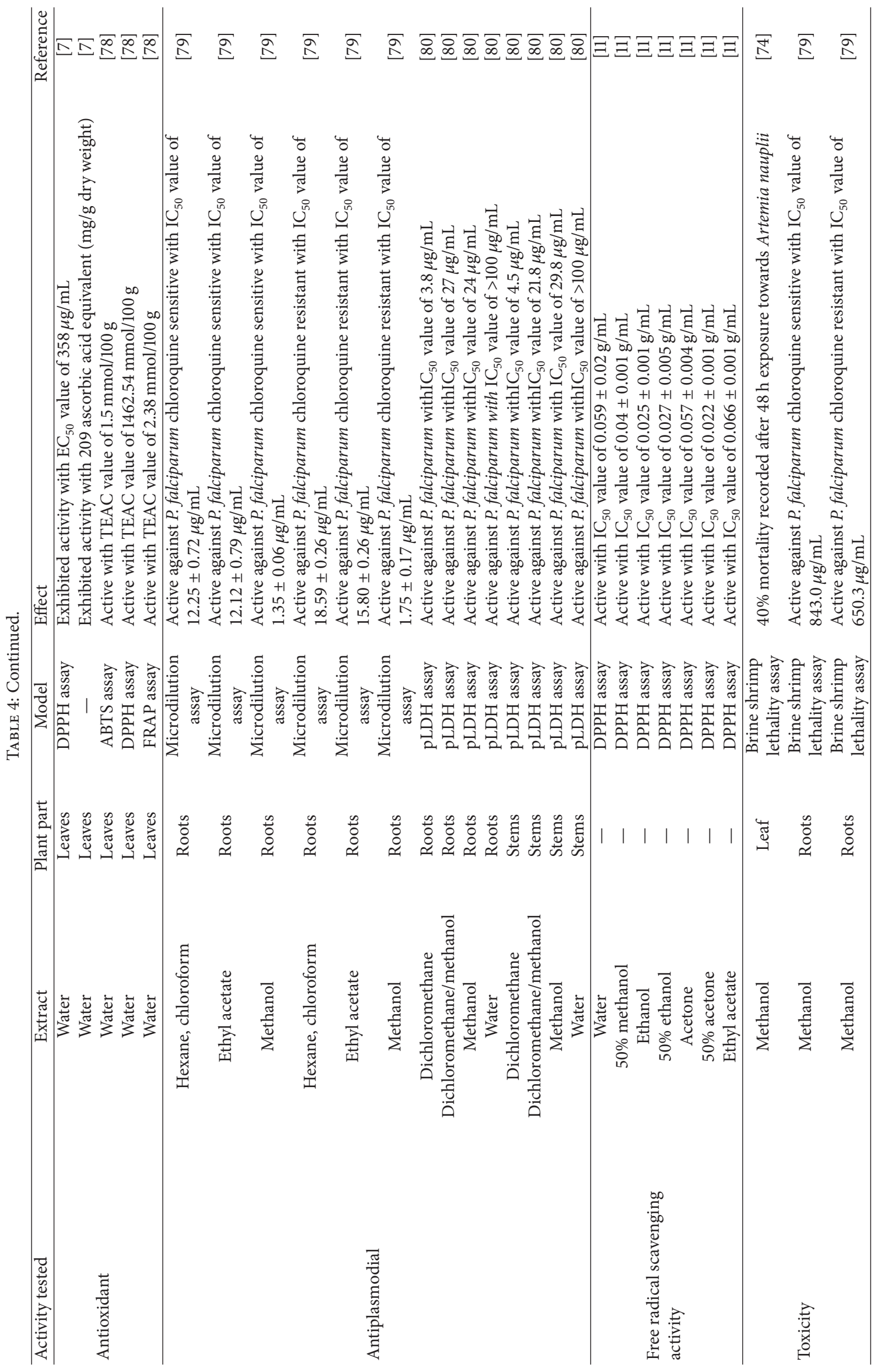


strengthen the view that L. javanica is a potential source of antidiabetic agents and to some extent validate the traditional use of the plant species mixed with C. obliquus to form a herbal concoction known in KwaZulu Natal province, South Africa, as "imbiza” used against diabetes [27].

4.3. Antimalarial Activity. Govere et al. [142] found that topical application of L. javanica alcohol extract leads to 76.7\% protection against Anopheles arabiensis for 4 hours. Lippia javanica has been used as a mosquito repellent by the rural communities in Zimbabwe for a long time and previous studies have shown that essential oils from the species have very strong and lasting repellent activity against female $A$. arabiensis [64]. Research by Lukwa et al. [4] revealed that topical application of $5 \mathrm{mg} / \mathrm{cm}^{2}$ of L. javanica leads to $100 \%$ protection against Anopheles aegypti for 8 hours. Mavundza et al. [154] screened dichloromethane and ethanol leaf extracts of $L$. javanica for adulticidal activity against $A$. arabiensis. The authors observed dichloromethane and ethanol activities of $45 \%$ and $55 \%$ mosquito mortality, respectively. These findings strengthen the view that L. javanica is a potential source of antimalarial agents and to some extent validate the traditional use of the plant species as mosquito repellent in India [47], South Africa [34, 49, 58], and Zimbabwe [4, 48].

4.4. Antioxidant Activity. Leaf infusions of L. javanica exhibited antioxidant activity with $\mathrm{EC}_{50}$ value of $358 \mu \mathrm{g} / \mathrm{mL}$ and contained $14.8 \mathrm{mg} / \mathrm{mL}$ of dry weight gallic acid equivalent phenolic compounds [7]. The $\mathrm{EC}_{50}$ value of $358 \mu \mathrm{g} / \mathrm{mL}$ obtained for L. javanica by Shikanga et al. [7] compares well to those of many commercial teas, including antioxidant capacity of Rooibos Fresh Pack ${ }^{\mathrm{TM}}$ herbal teas (A. linearis) with the best antioxidant activity of $333 \mu \mathrm{g} / \mathrm{mL}$. The high antioxidant activities displayed by $L$. javanica infusions can be partially attributed to the high levels of verbascoside 2 $(1.5 \mathrm{mg} / \mathrm{g}$ dry weight) reported by Olivier et al. [81] in the leaf extract of the species. Earlier research by Muchuweti et al. [125] reported $74.4 \%$ inhibition of the DPPH radical by an ethanolic leaf extract of $L$. javanica. Lekganyane et al. [75] reported antioxidant activity in L. javanica and the acetone extracts of the species displayed antioxidant activity on BEA chromatogram [77]. Bhebhe et al. [10] reported the antioxidant activities of $L$. javanica based on the DPPH, reducing power and inhibition of phospholipid peroxidation assays. Free radical scavenging activity of $L$. javanica is attributed to phenolic compounds since these compounds have an ideal structural chemistry for free radical scavenging activity [155]. Bhebhe et al. [11] determined the effect of several solvents on the free radical scavenging activity of L. javanica using the DPPH assay. Free radical scavenging activity expressed as $\mathrm{IC}_{50}$ ranged from $0.022 \pm 0.001 \mathrm{~g} / \mathrm{mL}$ to $0.066 \pm 0.001 \mathrm{~g} / \mathrm{mL}$; see Table 4 .

4.5. Antiplasmodial Activity. Prozesky et al. [144] evaluated L. javanica leaf acetone extract for in vitro antiplasmodial activity using PfUP1, a chloroquine resistant strain of the malaria parasite Plasmodium falciparum by means of the flow cytometric test. The $\mathrm{IC}_{50}$ value for $L$. javanica was $4.26 \mu \mathrm{g} / \mathrm{mL}$. Manenzhe et al. [2] evaluated essential oil, piperitenone 162, isolated from L. javanica for antiplasmodial activity using chloroquine diphosphate as positive control and found it active against a chloroquine sensitive strain of $P$. falciparum in micromolar concentrations with $\mathrm{IC}_{50}$ of $8 \mu \mathrm{g} / \mathrm{mL}$. Clarkson et al. [80] evaluated L. javanica roots and stems extracts for in vitro activity against $P$. falciparum using the parasite lactase dehydrogenase ( $\mathrm{pLDH})$ assay and chloroquine diphosphate (Sigma) as the positive control. The dichloromethane, methane, and water extracts showed $\mathrm{IC}_{50}$ values ranging from 3.8 to $>100 \mu \mathrm{g} / \mathrm{mL}$; see Table 4 . Omolo et al. [145] screened the essential oil of L. javanica for fumigant toxicity to Anopheles gambiae which exhibited $\mathrm{LD}_{50}$ of $4.3 \times$ $10^{-3} \mathrm{mg} \mathrm{cm}^{-3}$. Ayuko et al. [79] showed that L. javanica root extracts have antiplasmodial activity against $P$. falciparum with $\mathrm{IC}_{50}$ ranging from 1.35 to $18.59 \mu \mathrm{g} / \mathrm{mL}$; see Table 4 . Lippialactone 21, derived from the ethyl acetate extract of aerial parts of L. javanica, exhibited some activity against the chloroquine sensitive D10 strain of P. falciparum with an $\mathrm{IC}_{50}$ value of $9.1 \mu \mathrm{g} / \mathrm{mL}$ and is also mildly cytotoxic [84]. Compared to chloroquine, the compound is approximately 2000 times less active against the D10 strain of $P$. falciparum [84].

4.6. Antimicrobial Activities. Lippia javanica is widely used in the treatment of a wide range of infectious diseases caused by microorganisms. Viljoen et al. [3] determined the antimicrobial properties of L. javanica by evaluating the time kill studies of the species' essential oil using the disc diffusion assay on three respiratory pathogens Klebsiella pneumoniae, Cryptococcus neoformans, and Bacillus cereus. This study showed that the killing rate was greatest for K. pneumoniae followed by $C$. neoformans and very little reduction of microbial populations was observed for B. cereus. The efficacy of $L$. javanica oil for K. pneumoniae showed a killing rate within 30 minutes for the concentrations $0.25,0.5,0.75$, and $1 \%$, C. neoformans showed a killing rate for concentrations 0.5 , 0.75 , and $1 \%$ within 1 hour, and the lowest concentration of $0.25 \%$ took 8 hours before a bactericidal effect was noted while $B$. cereus showed some reduction in colonies [3]. The positive antimicrobial activity of $L$. javanica as revealed by the time kill study could be attributed to linalool 120 which averages between 65 and $70 \%$ in yield $[3,5,88,90]$ and has known antimicrobial properties [93, 156-159]. These findings somehow corroborate the traditional use of L. javanica as herbal medicine for a wide range of bacterial and fungal respiratory ailments indicated in Table 1.

Manenzhe et al. [2] evaluated essential oil, piperitenone 162, isolated from L. javanica for antibacterial activity on cultures of Bacillus subtilis, Staphylococcus aureus, and Escherichia coli using imipenem, cefazolin, and ampicillin as positive controls. The authors found piperitenone $\mathbf{1 6 2}$ to inhibit $S$. aureus and E. coli at $1 \%$ dilution. Acetone, hexane, and methanol leaf extracts and essential oil isolated from L. javanica showed some activity against fifteen Grampositive and Gram-negative bacteria with MIC values ranging from 1.5 to $>12 \mathrm{mg} / \mathrm{mL}$ [60]; see Table 4 . In a similar study, Samie et al. [73] demonstrated that a pure compound piperitenone $\mathbf{1 6 2}$ isolated from L. javanica has antibacterial activities against Acinetobacter calcoaceticus, Micrococcus 
kristinae, Salmonella typhi, and S. aureus using dimethyl sulphoxide and kanamycin as controls, with MIC values ranging from 12 to $50 \mu \mathrm{g} / \mathrm{mL}$; see Table 4 . Shikanga et al. [7] evaluated the antibacterial activity of $L$. javanica methanolic leaf extract against $S$. aureus, Enterococcus faecalis, E. coli, and Pseudomonas aeruginosa using the serial microdilution method with gentamycin (Virbac ${ }^{\circledR}$ ) and acetone as positive and negative controls, respectively. Lippia javanica displayed antibacterial activities with MIC values ranging from 0.13 to $0.42 \mathrm{mg} / \mathrm{mL}$ against all four pathogens; see Table 4 . The obtained minimum inhibitory concentrations are promising, since natural products with MIC values below $1 \mathrm{mg} / \mathrm{mL}$ are generally considered to be noteworthy findings [160]. Lippialactone 21, derived from the ethyl acetate extract of aerial parts of $L$. javanica, exhibited some activity against the E. coli and S. aureus at a concentration of $10 \mathrm{mg} / \mathrm{mL}$ [84]. Lekganyane et al. [75] reported antibacterial activity of $L$. javanica acetone leaf extracts against E. coli, E. faecalis, $P$. aeruginosa, and $S$. aureus with MIC values ranging from 0.32 to $0.64 \mathrm{mg} / \mathrm{mL}$ and total activity of the same species ranging from 127 to $253 \mathrm{mg} / \mathrm{mL}$; see Table 4. Methanol and water leaf extracts of $L$. javanica exhibited some antiproteus activity against Proteus mirabilis and Proteus vulgaris with MIC values $<2000 \mu \mathrm{g} / \mathrm{mL}$ with standard discs of ampicillin $(2 \mu \mathrm{g})$ and chloramphenicol $(10 \mu \mathrm{g})$ as positive controls [74]. Some of the antibacterial properties of $L$. javanica can be attributed to the phytochemical constituents of the species; for example, the phenolic compound apigenin 7 is a well-known antibacterial agent $[7,134]$. Apigenin 7 was shown to be highly active against Vibrio cholera and E. faecalis [161], while Basile et al. [162] reported the inhibition of S. typhi, P. mirabilis, and $P$. aeruginosa by the compound. Therefore, results from these antibacterial evaluations of $L$. javanica give credence to the use of the species' infusions against bacterial infections and other related diseases.

Shikanga et al. [126] investigated the antifungal activities of leaf extracts and essential oil compounds isolated from $L$. javanica leafy extracts against a Guazatine ${ }^{\circledR}$-resistant strain of Penicillium digitatum. The methanolic leafy extracts, isoverbascoside $\mathbf{3}$ and verbascoside $\mathbf{2}$ compounds, isolated from $L$. javanica inhibited fungal growth at concentrations above $0.6 \mathrm{mg} \cdot \mathrm{mL}^{-1}$, causing significant inhibition of mycelial growth. Verbascoside $\mathbf{2}$ is well-known for its antimicrobial properties and has been found to inhibit viruses, bacteria, and fungi [163]. Similarly, Samie et al. [143] investigated antifungal effects of acetone and hexane leaf extracts of $L$. javanica against Candida albicans, Candida krusei, and C. neoformans isolated from AIDS patients using the microdilution method with nystatin, Roche, and DMSO as positive and negative controls, respectively. Noteworthy moderate antifungal activities were recorded from C. krusei with MIC value of $1.88 \mathrm{mg} / \mathrm{mL}$ and other recorded MFC and MIC values for other species ranged from $1.88 \mathrm{mg} / \mathrm{mL}$ to $>7.5 \mathrm{mg} / \mathrm{mL}$; see Table 4. Thembo et al. [76] investigated the antifungal activity of aqueous and organic extracts of $L$. javanica using a serial microdilution assay. Generally, extracts of $L$. javanica exhibited weak activity; see Table 4.
4.7. Antimycobacterial Activity. Mujovo et al. [83] evaluated L. javanica compounds against a drug-sensitive strain of Mycobacterium tuberculosis using the radiometric respiratory techniques. Of all the isolated compounds, only one triterpenoid carboxylic acid, euscaphic acid 172, exhibited antimycobacterial activity with MIC value of $50 \mu \mathrm{g} \mathrm{mL}^{-1}$ against this strain. In a similar study, the leaf extract of L. javanica exhibited antimycobacterial activity against $M$. smegmatis in an evaluation which used microdilution assay and rifampicin as control [77]. Acetone extract was the best extractant with MIC value of $0.47 \mathrm{mg} / \mathrm{mL}$; it extracted antibacterial agents which was indicated by the lowest MIC value [77]. Masoko and Nxumalo [77] also evaluated the total activity of $L$. javanica which averaged $13 \mathrm{~mL} / \mathrm{g}$ suggesting that the extract prepared from one gram of $L$. javanica could be diluted to a volume of $13 \mathrm{~mL}$ and will still inhibit M. smegmatis efficiently. According to Semenya and Maroyi [115], tuberculosis caused by M. tuberculosis is a serious disease requiring effective strategies and tools to control and manage it. Therefore, preliminary evaluations done by Mujovo et al. [83] and Masoko and Nxumalo [77] serve as a scientific validation for the use of $L$. javanica in traditional medicine for treatment of tuberculosis and other respiratory ailments in South Africa [24, 27, 115] and Uganda [43] as well as their efficiency in tuberculosis drug discovery.

4.8. Antiviral Activity. Mujovo et al. [83] found that (E)2(3)-tagetenone epoxide 42 and piperitenone 162 inhibited the HIV-1 reverse transcriptase enzyme by $91 \%$ and $53 \%$, respectively, at $100 \mu \mathrm{g} \mathrm{mL}^{-1}$ based on a nonradioactive HIV RT colorimetric ELISA kit. Little is known about the HIV RT activity of $L$. javanica extracts or compounds, but flavonoids are known to be active against viral RT and also as potent inhibitors of the cellular alpha and beta DNA polymerase [83], while luteolin 12 is active against HIV RT [164, 165]. Lippia javanica is traditionally used to treat HIV/AIDS symptoms in South Africa $[65,66]$ and several viral and HIV/AIDS opportunistic diseases and infections such as bronchitis [15, 19-22], chicken pox [50], diarrhoea [17, 34, $37,44,113]$, measles [14, 20, 38], pneumonia [14], shingles [15], and venereal diseases [44]. Despite significant advances in the utilization of $L$. javanica in southern Africa over the years for numerous viral diseases (Table 1), very little antiviral evaluations have been done on crude extracts and purified compounds of the species. There is need, therefore, for more pharmacological research as L. javanica could be harbouring potent (RT) inhibitors which could be useful for the development of new pharmaceutical products important for use against viral diseases and infections.

4.9. Pesticidal Effects. Magano et al. [95] evaluated the repellent effects of hexane extracts of $L$. javanica essential oil using the in vitro tick climbing repellency bioassay on adults of Hyalomma marginatum rufipes Koch ticks. The authors found that $107 \mathrm{mg} / \mathrm{mL}$ caused repellency index of $100 \%$ at one hour and 30 minutes. In a similar study by Madzimure et al. [120], L. javanica aqueous leaf extracts at $10 \%$ and $20 \% \mathrm{w} / \mathrm{v}$ were effective at controlling cattle ticks (Amblyomma species, 
Boophilus species, Hyalomma species, Rhipicephalus appendiculatus, and Rhipicephalus evertsi evertsi) and were as good as the positive control amitraz-based acaricide Trickbuster ${ }^{\circledR}$. These authors found no parasites on microscopic examination of the Giemsa-stained thin blood smear collected from treated cattle implying that the animals did not suffer from clinical tick-borne diseases. Similarly, Nyahangare et al. [59] tested the pesticidal activity of $L$. javanica water extracts against cattle ticks. The authors found no significant difference between cattle treated with a commercial synthetic acaricide and those under L. javanica treatment. MartinezVelazquez et al. [166] evaluated pesticidal effects of two essential oils, namely, $\gamma$-terpinene 82 and $\rho$-cymene 99, isolated from Lippia graveolens Kunth against 10-day-old Rhipicephalus (Boophilus) microplus (Canestrini) tick larvae using the larval packet test bioassay. The two essential oils produced high mortality ranging from 90 to $100 \%$ in all tested concentrations of 20 to $1.25 \%$ (v/v). Therefore, L. javanica can provide an effective tick control option where synthetic products are unavailable or unaffordable particularly in remote rural areas in sub-Saharan Africa. Lippia javanica is popular for tick control and management among resource-poor smallholder farmers in South Africa $[58,95]$ and Zimbabwe $[59,60,120]$. While these preliminary evaluations may serve as confirmation that $L$. javanica has some bioactivities against ticks, a comprehensive method of tick control is required for the resource-constrained smallholder farmers based on ethnopharmacological properties of L. javanica.

McGaw et al. [146] screened L. javanica for the anthelmintic test systems using the free living nematode Caenorhabditis elegans. The crude ethanol and hexane extracts showed some activity at a concentration of $2 \mathrm{mg} / \mathrm{mL}$, with the 7-day incubation assay appearing to be more sensitive than the shorter assay. Earlier research by Mwangi et al. [1] indicated that L. javanica was active against Aedes aegypti larvae and Sitophilus zeamais Motschulsky (maize weevil). Katsvanga and Chigwiza [147] reported that $L$. javanica is an effective natural pesticide which can be used to control aphid species (Brevicoryne brassicae). In their study, Katsvanga and Chigwiza [147] found that 1:1 powdered aqueous leaf extract of $L$. javanica reduced B. brassicae by $53.2 \%$ against $78.3 \%$ and $96.7 \%$ of two synthetic pesticides, Aphid kill and Bexadust "L," respectively. Chikukura et al. [149] found L. javanica powdered leaf extracts to have insecticidal properties with potential to control grain damage by $21-33 \%$. Mashela et al. [148] reported that the application of ground L. javanica leaves to soil in nematodeinfested (Meloidogyne incognita) pots reduced the nematode numbers by $79-92 \%$ and significantly increased fresh fruit yield, dry shoot mass, plant height, and stem diameter of the tomato plants, as well as levels of potassium, nitrogen, and manganese in leaf tissue. Muzemu et al. [150] evaluated water extracts of $L$. javanica leaf powder for pesticidal effects against rape (Brassica napus L.) aphids, B. brassicae, and tomato (Solanum lycopersicum Lam.) red spider mites, and Tetranychus evansi as alternatives to conventional pesticides. Lippia javanica reduced B. brassicae and Tetranychus evansi by $12.5 \%$ and $63 \%$, respectively [150]. The study demonstrated that $L$. javanica has pesticidal effects on B. brassicae and $T$. evansi. The reduced number of B. brassicae and T. evansi could be due to $L$. javanica's extracts having repellent, toxic, and antifeedant effects since the species has essential oils with pesticidal properties [2]. Therefore, these findings indicate that $L$. javanica has both nematicidal and plant growth-promoting properties.

4.10. Toxicity and Cytotoxicity Activity. Lippia javanica is known to cause liver damage and photosensitisation in livestock, resulting in stock losses [167]. Triterpenoids isolated from the genus Lippia are icterogenic and cause jaundice as a result of liver damage [167]. The characteristic swelling, yellowing, and later peeling of unpigmented skin are due to the presence of phylloerythrin, a photodynamic porphyrin that reacts with sunlight and causes severe cell damage [167]. The compound is normally formed when chlorophyll is broken down by microorganisms in the rumen, but it now accumulates in the liver as a result of the damage caused by triterpenoids [167]. In view of the known toxicity of Lippia species, the prolonged use of high doses of L. javanica is potentially harmful [167]. Lippia javanica showed low toxicity after $48 \mathrm{~h}$ exposure with the percentage of mortality below $50 \%[74]$.

Ayuko et al. [79] evaluated the toxicity of $L$. javanica using a brine shrimp cytotoxicity assay with $\mathrm{LC}_{50}$ value of $1138 \pm 1.33 \mu \mathrm{g} / \mathrm{mL}$. Ayuko et al. [79] found the cytotoxicity to antiplasmodial activity ratios for the methanolic extracts of the two tested strains to be 843.0 and 650.3 , and since these are greater than 100 , it may be concluded that the extracts are of low toxicity. Samie et al. [73] demonstrated that a pure compound piperitenone $\mathbf{1 6 2}$ isolated from L. javanica essential oil has low cytotoxicity activity against intestinal adenocarcinoma cells (i.e., the HCT-8 monolayers with $\mathrm{IC}_{50}$ of $265.6 \pm 5.3 \mu \mathrm{g} / \mathrm{mL}$ ). Lukwa [64] evaluated the toxicity of $L$. javanica aqueous leaf extracts using sexually mature BALB/c mice with the placebo as control. Within 48 hours, all mice fed with the $L$. javanica leaf aqueous extract at $12.5-37.5 \% \mathrm{v} / \mathrm{v}$ were lethargic, and the overall mortality was $37.5 \%$. Previous research by Manenzhe et al. [2] showed that hydrodistillation of $L$. javanica leaves, flowers, and stems produced oil that was poisonous against $P$. falciparum when diluted to $1 \%(\mathrm{v} / \mathrm{v})$. These findings imply that, despite its apparent safety, water extracts of $L$. javanica leaves may have deleterious health implications on humans and animals if consumed at very high doses.

Many compounds that have been isolated from L. javanica including phenolic glycosides, flavonoids, and essential oils are not known to have acute toxic properties with the exception of icterogenin 173. Icterogenin $\mathbf{1 7 3}$ has been shown to inhibit biliary excretion in rabbits [168]. Reports in literature indicate that the consumption of xanthine $\mathbf{2 2}$ has resulted in mammalian toxicity. According to Madzimure et al. [64], xanthine 22 is a demethylated derivative of caffeine with pharmacological actions such as central nervous system (CNS) stimulation, relaxation of smooth muscle (especially bronchial muscle), myocardial stimulation, peripheral vasoconstriction, and diuresis. Considering the widespread use of $L$. javanica as herbal tea and medicine, it is important 
to determine if any toxicological effects can occur from its chronic or subchronic usage.

4.11. Other Activities. Mpofu et al. [169] determined the effect of inclusion of L. javanica leaf meal in broiler diets on growth performance, carcass characteristics, and fatty acid profiles. The authors found that the L. javanica fed broilers had higher total polyunsaturated fatty acids and n-3 fatty acids. The findings from the study showed that inclusion of $L$. javanica in broiler diets at $5 \mathrm{~g} / \mathrm{kg}$ feed has positive influences on growth performance, carcass characteristics, and fatty acid profiles of broiler meat and, therefore, L. javanica has potential as growth-promoting feed additive in broilers. Samie et al. [73] evaluated antiamoebic activity of a pure compound piperitenone $\mathbf{1 6 2}$ isolated from L. javanica essential oil against Entamoeba histolytica using microdilution method with metronidazole as the positive control, diluents (i.e., culture medium with an appropriate concentration of dimethyl sulphoxide as the negative control), and a blank (i.e., culture medium without dimethyl sulphoxide). Samie et al. [73] demonstrated that piperitenone 162 had marked antiamoebic activity with $\mathrm{IC}_{50}$ value of $25 \mu \mathrm{g} / \mathrm{mL}$. More research is required as $L$. javanica could be harbouring potent antiamoebic properties which could be useful for managing amoebiasis, an infection that remains a significant cause of morbidity and mortality worldwide.

\section{Conclusion}

Lippia javanica has been used in African and Asian countries as herbal tea and medicine for many centuries. Utilization of L. javanica because of its flavour and medicinal properties forms the basis of the current demand for the plant species in central, eastern, and southern Africa. Research on $L$. javanica over the past decade on health promoting properties has greatly contributed to the increased consumption of the species as herbal or recreational tea. The focus of this research has been on phytochemical compounds, particularly phenolic content and antioxidant and free radical scavenging activities. Phenolic compounds present in L. javanica are largely responsible for the antioxidant properties possessed by the species. More research in this regard is required and future research should focus on more comprehensive chemical characterization of both crude and pure extracts and evaluate potential for commercialization and development of nutraceutical products based on traditional uses of $L$. javanica. Most of the pharmacological researches conducted on L. javanica so far have focused on the phytochemistry and biological properties of leaves, and little or no research has been done on roots and other plant parts. Therefore, future research on the species should focus on other plant parts, for example, flowers, roots, and stems, as well as organ-to-organ, age, and seasonal variation evaluations in the phytochemical content and pharmacological activities of the species.

The recent increase in the demand for L. javanica products may partly be ascribed to growing body of scientific evidence indicating important health benefits. Lippia javanica is widely sold as herbal tea in Botswana, South Africa, and Zimbabwe. Leaves and stems of L. javanica are also sold as herbal medicines in the medicinal plant "muthi" markets in South Africa [35, 170]. For local people who rely on herbal medicines as part of their primary healthcare as well as cultural beliefs, they prefer L. javanica harvested from the wild and unprocessed plant parts sold in informal medicinal "muthi" markets [170]. In the past, there were no records of overexploitation of $L$. javanica wild populations in southern Africa, resulting in Raimondo et al. [171] listing the species as Least Concern (LC) under the IUCN Red List Categories and Criteria version 3.1 of threatened species (http://www.iucnredlist.org). Recently, signs of overharvesting have been noted, where local people or plant traders have uprooted whole plants to supply medicinal plant "muthi" markets or use the plants as herbal medicines, brooms, or herbal tea. Therefore, large-scale commercial utilization of $L$. javanica is not sustainable if the species is harvested from the wild. Currently, L. javanica is cultivated on a commercial scale in Kenya [28] and South Africa [117] for essential oil production for the mosquito-repellent candles and perfume industry. Cultivation of $L$. javanica is therefore, a solution to the sustainability problems associated with harvesting of the species from the wild, and this option is also necessary for establishing commercial scale medicinal production and processing and trade enterprises. The success of commercial cultivation of L. javanica will depend on how the species is marketed as herbal tea and medicine and source of essential oil and health care products and as a source of functional foods.

Significant research has been made in the past 50 years into the chemistry and pharmacology of L. javanica. These studies have shown L. javanica to display various chemical and different biological activities some of which justify its ethnopharmacological utilization in variety of cultures. In the light of the evidence that L. javanica is combined with other plant species in traditional medicine, it will be valuable to investigate the possibility of synergistic effects of the different extracts. Deep phytochemical studies of L. javanica and its phytochemical properties, especially the mechanisms of action of its bioactive constituents to illustrate the correlation between ethnomedicinal uses and pharmacological activities, should be the focus of further research on the species. There is need for extensive in vivo experiments to validate the existing pharmacological activities. However, because L. javanica contains potentially toxic compounds, its toxicological properties need to be properly established via proper quality control of product development to ensure that potentially toxic components are kept below tolerance levels.

\section{Appendix}

\section{A. Chemical Compounds Isolated and Characterized from Lippia javanica}

See Table 5 . 
TABle 5

\begin{tabular}{|c|c|}
\hline Chemical compound & Reference(s) \\
\hline \multicolumn{2}{|l|}{ Phenolic compounds } \\
\hline Coumarin 1 & {$[4]$} \\
\hline Verbascoside 2 & {$[81]$} \\
\hline Isoverbascoside 3 & {$[81]$} \\
\hline Theveside-Na 4 & [82] \\
\hline Theveridoside 5 & [82] \\
\hline 4-ethylnonacosane 6 & {$[83]$} \\
\hline Apigenin 7 & {$[64,83]$} \\
\hline Cirsimaritin 8 & {$[64,83]$} \\
\hline $\begin{array}{l}\text { 6-Methoxy luteolin } \\
4^{\prime} \text {-methyl ether } 9\end{array}$ & {$[83]$} \\
\hline $\begin{array}{l}\text { 6-Methoxy luteolin } \\
3^{\prime}, 4^{\prime}, 7 \text {-trimethyl ether } \mathbf{1 0}\end{array}$ & {$[83]$} \\
\hline Crassifolioside $\mathbf{1 1}$ & {$[64]$} \\
\hline Luteolin 12 & {$[64]$} \\
\hline Diosmetin 13 & {$[64]$} \\
\hline Chrysoeriol 14 & {$[64]$} \\
\hline Tricin 15 & {$[64]$} \\
\hline Isothymusin 16 & {$[64]$} \\
\hline Eupatorin 17 & {$[64]$} \\
\hline 5-Dimethyl noboletin $\mathbf{1 8}$ & {$[64]$} \\
\hline Genkwanin 19 & {$[64]$} \\
\hline Salvigenin 20 & {$[64]$} \\
\hline Lippialactone 21 & {$[84]$} \\
\hline \multicolumn{2}{|l|}{ Alkaloid } \\
\hline Xanthine 22 & {$[64]$} \\
\hline \multicolumn{2}{|l|}{ Amino acids } \\
\hline$\alpha$-Aminobutyric acid 23 & {$[85,86]$} \\
\hline Valine 24 & {$[86]$} \\
\hline Isoleucine 25 & {$[86]$} \\
\hline Asparagine 26 & {$[86]$} \\
\hline Phenylalanine 27 & {$[86]$} \\
\hline$\alpha$-Aminoadipic acid 28 & {$[86]$} \\
\hline Lysine 29 & {$[86]$} \\
\hline Histidine 30 & {$[86]$} \\
\hline Tyrosine 31 & {$[86]$} \\
\hline Tryptophan 32 & {$[86]$} \\
\hline Alanine 33 & {$[85]$} \\
\hline Glycine 34 & {$[85]$} \\
\hline Proline 35 & {$[85]$} \\
\hline Serine 36 & {$[85]$} \\
\hline Glutamine acid 37 & [85] \\
\hline$\beta$-Alanine 38 & [85] \\
\hline Glutamine 39 & {$[85]$} \\
\hline$\beta$-Aminoisobutyric acid $\mathbf{4 0}$ & {$[85]$} \\
\hline 4-hydroxyproline 41 & {$[85]$} \\
\hline \multicolumn{2}{|l|}{ Essential oil } \\
\hline $\begin{array}{l}\text { (E)-2(3)-tagetenone } \\
\text { epoxide } \mathbf{4 2}\end{array}$ & [83] \\
\hline 4-Methyl-2-pentanone 43 & {$[3]$} \\
\hline$\alpha$-Pinene 44 & {$[3-5,87-91]$} \\
\hline
\end{tabular}

TABLE 5: Continued.

\begin{tabular}{|c|c|}
\hline Chemical compound & Reference(s) \\
\hline 1,3-5-Cycloheptatriene 45 & {$[4]$} \\
\hline (+)-2-Carene 46 & {$[4]$} \\
\hline 3-Carene 47 & {$[4]$} \\
\hline Eucalyptol 48 & {$[4]$} \\
\hline 1.8 myrcene 49 & {$[87]$} \\
\hline Ipsdienone $\mathbf{5 0}$ & {$[87]$} \\
\hline Caryophyllene 51 & {$[85]$} \\
\hline Geranial 52 & {$[5,92,93]$} \\
\hline 2,6-Dimethylstyrene $\mathbf{5 3}$ & [92] \\
\hline Geraniol 54 & {$[92]$} \\
\hline Octen-3-one 55 & {$[5]$} \\
\hline 6-Methyl-5-hepten-2-one 56 & {$[5]$} \\
\hline$\rho$-Mentha-1(7),8-diene 57 & {$[5]$} \\
\hline Artemisia ketone $\mathbf{5 8}$ & {$[5]$} \\
\hline Linalool oxide 59 & {$[5]$} \\
\hline Terpinen-4-ol 60 & {$[5]$} \\
\hline$(Z)-\beta$-Ocimenone 61 & {$[5]$} \\
\hline (E)- $\beta$-Ocimenone 62 & {$[5]$} \\
\hline Carvyl acetate 63 & {$[5]$} \\
\hline$\alpha$-Cubebene 64 & {$[5]$} \\
\hline Sesquithujene 65 & {$[5]$} \\
\hline Acora-3,5-diene 66 & {$[5]$} \\
\hline$\beta$-Bergamotene 67 & {$[5]$} \\
\hline Trans-calamenene $\mathbf{6 8}$ & [5] \\
\hline$\beta$-Alaskene 69 & {$[5]$} \\
\hline$\gamma$-Cadinene $\mathbf{7 0}$ & [5] \\
\hline
\end{tabular}

$[3,88,89,91]$

Nerolidol 73

(E)-Nerolidol 74

Spathulenol 75

Epi- $\alpha$-muurolol 76

$\alpha$-Longipinene 77

$[3,88,89]$

[5]

Chrysanthenone 78

$[3,5,90,91]$

[90]

$\alpha$-Amorphene 80

[91]

$\alpha$-Thujene 81

[91]

$\gamma$-Terpinene 82

[91]

$\alpha$-Cubebene 83

[91]

[91]

Bicyclosesquiphellandrene 85

,, $88-91]$

Camphene 86

$[3,5,91]$

$\beta$-Pinene 87

Sabinene $\mathbf{8 8}$

$[3,5,87,90,91]$

Myrcene 89

$\alpha$-Phellandrene 90

[3, 5, 87-89, 91-95]

[3, 5, 88, 89]

[3]

2-Methylbutyl isobutyrate 91

[3, 5, 88-94]

Limonene 92

$[3,5,90,91,95]$

1,8-Cineole 93

$[3,4,88,89,91]$ 
TABLe 5: Continued.

\begin{tabular}{|c|c|}
\hline Chemical compound & Reference(s) \\
\hline (Z)-3-Hexenal 95 & {$[3]$} \\
\hline (Z)- $\beta$-Ocimene 96 & {$[3,5,88,89,91]$} \\
\hline (E)- $\beta$-Ocimene 97 & {$[3,5,88,89,91]$} \\
\hline Isomyrcenol 98 & [3] \\
\hline p-Cymene 99 & {$[3,5,85,88-91]$} \\
\hline 2-Methylbutyl-2-methyl butyrate 100 & {$[3]$} \\
\hline Terpinolene 101 & {$[3]$} \\
\hline Dihydrotagetone 102 & {$[3,88,89,91,95]$} \\
\hline Cis-alloocimene 103 & {$[3,88,89]$} \\
\hline (Z)-3-Hexen-1-ol 104 & [3] \\
\hline 6,7-Epoxymyrcene 105 & {$[3]$} \\
\hline Nonanal 106 & {$[3]$} \\
\hline Perillene 107 & {$[3,91]$} \\
\hline Ipsenone 108 & {$[3,87-89,95]$} \\
\hline Trans-Linalool oxide (furanoid) 109 & {$[3,88-90]$} \\
\hline 1-Octen-3-ol 110 & {$[3,88,89]$} \\
\hline Cis-1,2-limonene epoxide 111 & [3] \\
\hline Ttrans-1,2-limonene epoxide $\mathbf{1 1 2}$ & {$[3]$} \\
\hline cis-Linalool oxide (furanoid) 113 & {$[3,88-90]$} \\
\hline$\alpha$-Copaene 114 & {$[3,5,88-90]$} \\
\hline Cis-tagetone 115 & {$[3,88,89]$} \\
\hline Trans-tagetone 116 & {$[3,88,89]$} \\
\hline Camphor 117 & {$[3,5,88-90,93,94]$} \\
\hline$\beta$-Bourbonene 118 & {$[3,5,91]$} \\
\hline Benzaldehyde 119 & {$[3,5]$} \\
\hline Linalool 120 & $\begin{array}{c}{[3,5,85,88-} \\
90,92,93]\end{array}$ \\
\hline Trans- $\alpha$-bergamotene $\mathbf{1 2 1}$ & [3] \\
\hline$\alpha$-Cedrene 122 & {$[3,5]$} \\
\hline Myrcenone 123 & {$[3,5,83,91]$} \\
\hline$\beta$-Caryophyllene $\mathbf{1 2 4}$ & {$[3,5,87-91,93,94]$} \\
\hline $\begin{array}{l}\text { 2-Methyl-6-methylene-3,7-octadien-2-ol } \\
125\end{array}$ & {$[3]$} \\
\hline Trans-p-mentha-2,8-dien-1-ol 126 & {$[3]$} \\
\hline Cis-p-mentha-2,8-dien-1-ol 127 & {$[3]$} \\
\hline Alloaromadendrene $\mathbf{1 2 8}$ & {$[3,5,88,89]$} \\
\hline (Z)- $\beta$-Farnesene 129 & {$[3]$} \\
\hline (E)- $\beta$-Farnesene 130 & {$[3,5]$} \\
\hline$(E, E)-\alpha$-Farnesene $\mathbf{1 3 1}$ & {$[3,88,89]$} \\
\hline Ipsdienol 132 & [3] \\
\hline (Z)-3-Hexenyl tiglate $\mathbf{1 3 3}$ & [3] \\
\hline Isovaleric acid 134 & [3] \\
\hline$\alpha$-Humulene 135 & {$[3,5,88,89,91]$} \\
\hline$\alpha$-Acoradiene $\mathbf{1 3 6}$ & [3] \\
\hline$\beta$-Acoradiene 137 & [3] \\
\hline$\gamma$-Muurolene 138 & {$[3,5,88,89]$} \\
\hline$\alpha$-Muurolene 139 & {$[3,5,88-90]$} \\
\hline Cis-tagetenone 140 & [3] \\
\hline
\end{tabular}

TABLE 5: Continued.

\begin{tabular}{|c|c|}
\hline Chemical compound & Reference(s) \\
\hline Trans-tagetenone $\mathbf{1 4 1}$ & {$[3]$} \\
\hline Borneol 142 & {$[3,5,88-90]$} \\
\hline Verbenone 143 & {$[3,91]$} \\
\hline Germacrene-D 144 & {$[3,87-89,93]$} \\
\hline$\beta$-Bisabolene 145 & {$[3,5]$} \\
\hline$\gamma$-Bisabolene 146 & {$[3]$} \\
\hline Trans-carvyl acetate $\mathbf{1 4 7}$ & {$[3]$} \\
\hline Carvone 148 & {$[3,5,91]$} \\
\hline Bicyclogermacrene 149 & {$[3,5,88,89,91]$} \\
\hline$\beta$-Curcumene 150 & {$[3]$} \\
\hline Ar-curcumene 151 & {$[3]$} \\
\hline Cis-piperitol 152 & {$[3]$} \\
\hline 2-Methyl-2-butenoic acid 153 & {$[3]$} \\
\hline Trans-p-mentha-1(7),8-dien-2-ol 154 & {$[3]$} \\
\hline Cis-p-mentha-1(7),8-dien-2-ol 155 & {$[3]$} \\
\hline $\begin{array}{l}\text { 2,6-Dimethyl-3(E),5(E),7-octatriene-2-ol } \\
156\end{array}$ & {$[3,88,89]$} \\
\hline Trans-carveol 157 & {$[3]$} \\
\hline Calamenene $\mathbf{1 5 8}$ & {$[3]$} \\
\hline Carvone oxide 159 & {$[3]$} \\
\hline Isopiperitenone $\mathbf{1 6 0}$ & {$[3]$} \\
\hline Cis-carveol 161 & [3] \\
\hline Piperitenone 162 & {$[2,3,73,83]$} \\
\hline Isocaryophyllene oxide $\mathbf{1 6 3}$ & {$[3,88,89]$} \\
\hline Caryophyllene oxide 164 & {$[3-5,88-90]$} \\
\hline Humulene epoxide II 165 & {$[3,5,88,89]$} \\
\hline Hexahydrofarnesyl acetone $\mathbf{1 6 6}$ & {$[3]$} \\
\hline Spathulenol 167 & {$[3]$} \\
\hline Eugenol 168 & {$[3,5]$} \\
\hline Germacrene-D-4-ol 169 & {$[3]$} \\
\hline $\begin{array}{l}\text { Caryophylla-2(12),6(13)-dien-5 } \beta \text {-ol } \\
\text { (=Caryophylladienol I) } \mathbf{1 7 0}\end{array}$ & {$[3]$} \\
\hline $\begin{array}{l}\text { Caryophylla-2(12),6(13)-dien-5 } \alpha \text {-ol } \\
\text { (=Caryophylladienol II) } \mathbf{1 7 1}\end{array}$ & {$[3]$} \\
\hline Euscaphic acid 172 & {$[83]$} \\
\hline Icterogenin 173 & {$[96]$} \\
\hline
\end{tabular}

\section{B. Chemical Structures of Phenolic Compounds, Alkaloids, Amino Acids, and Essential Oils Isolated from Lippia javanica}

See Figure 4.

\section{Competing Interests}

The author declares that there is no conflict of interests regarding the publication of this paper. 


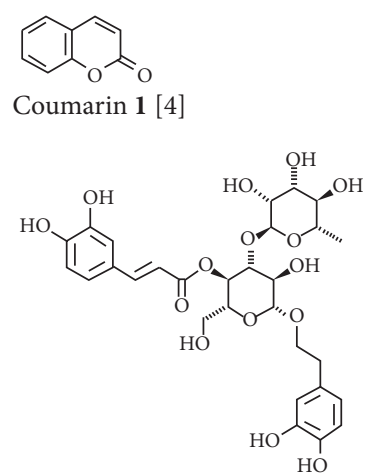

Verbascoside 2 [89]

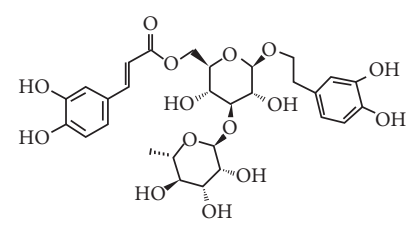

Isoverbascoside 3 [89]

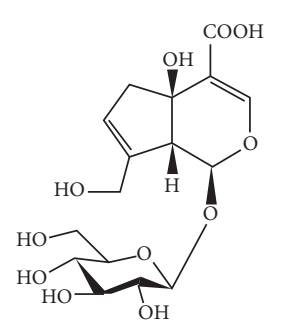

Theveside-Na 4 [90]

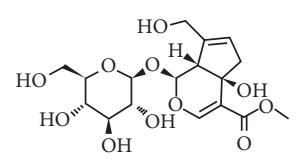

Theveridoside 5 [90]

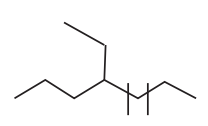

4-Ethylnonacosane 6 [91]

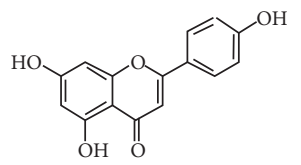

Apigenin 7 [120, 91]

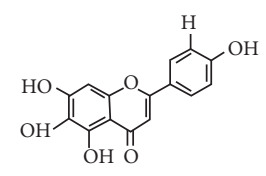

Cirsimaritin 8 [120, 91]

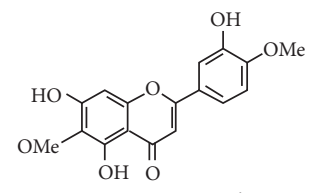

6-Methoxyluteolin $4^{\prime}$-methyl ether 9 [91]

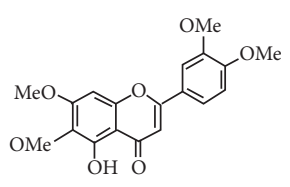

6-Methoxyluteolin $3^{\prime}, 4^{\prime}, 7$-trimethyl ether 10 [91]<smiles>CC1OC(OC2C(OCCc3ccc(O)c(O)c3)OC(CO)C(OC(=O)C=Cc3ccc(O)c(O)c3)C2OC2OC(C)C(O)C(O)C2O)C(O)C(O)C1O</smiles>

Crassifolioside 11 [120]<smiles>O=c1cc(-c2ccc(O)c(O)c2)oc2cc(O)cc(O)c12</smiles>

Luteolin 12 [120]<smiles>COc1ccc(-c2cc(=O)c3c(O)cc(O)cc3o2)cc1O</smiles>

Diosmetin 13 [120]<smiles>COc1cc(-c2cc(=O)c3c(O)cc(O)cc3o2)ccc1O</smiles>

Chrysoeriol 14 [120]<smiles>COc1cc(-c2cc(=O)c3c(O)cc(O)cc3o2)cc(OC)c1O</smiles>

Tricin 15 [120]

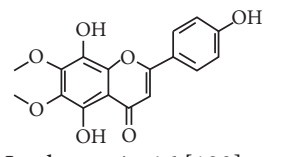

Isothymusin 16 [120]

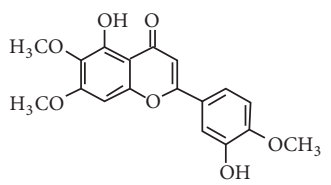

Eupatorin 17 [120]

FIgURE 4: Continued. 


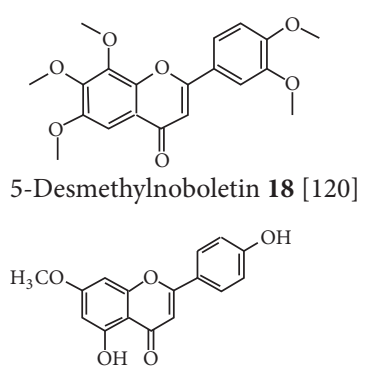

Genkwanin 19 [120]

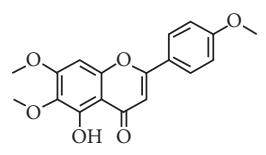

Salvigenin 20 [120]

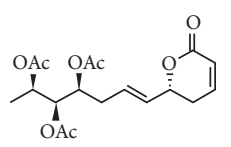

Lippialactone 21 [92]

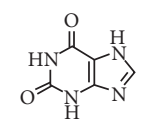

Xanthine 22 [120]<smiles>CCC(N)C(=O)O</smiles>

$\alpha$-Aminobutyric acid $23[93,94]$

$$
\underbrace{\mathrm{O}}_{\mathrm{NH}_{2}} \mathrm{OH}
$$

Valine 24 [94]<smiles>CCC(C)C(N)C(=O)O</smiles>

Isoleucine 25 [94]<smiles>NC(=O)CC(N)C(=O)O</smiles>

Asparagine 26 [94]<smiles>N[C@@H](Cc1ccccc1)C(=O)O</smiles>

Phenylalanine 27 [94]<smiles>C=C(O)CCCC(N)C(=O)O</smiles>

$\alpha$-Aminoadipic acid 28 [94]<smiles>NOC(=O)[C@@H](N)O</smiles>

Lysine 29 [94]<smiles>NC(Cc1cnc[nH]1)C(=O)O</smiles>

Histidine 30 [94]<smiles>NC(Cc1ccc(O)cc1)C(=O)O</smiles>

Tyrosine 31 [94]

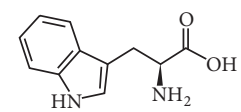

Tryptophan 32 [94]

$\mathrm{H}_{3} \mathrm{C} \underbrace{\mathrm{O}}_{\mathrm{NH}_{2}} \mathrm{OH}$

Alanine 33 [93]

$\mathrm{H}_{2} \mathrm{~N} \stackrel{\mathrm{N}}{\mathrm{OH}}_{\mathrm{OH}}$

Glycine 34 [93]

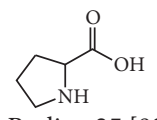

Proline 35 [93]

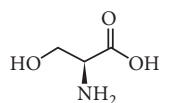

Serine 36 [93]

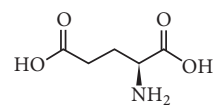

Glutamine acid 37 [93]

$\mathrm{H}_{2} \sim^{\mathrm{O}}{ }_{\mathrm{OH}}$

$\beta$-Alanine 38 [93]<smiles>NC(=O)CCC(N)C(=O)O</smiles>

Glutamine 39 [93]

$\overbrace{\mathrm{CH}_{3} \mathrm{~N}}^{\mathrm{O}}$

$\beta$-Aminoisobutyric acid 40 [93]<smiles>O=C(O)C1CC(O)CN1</smiles>

4-Hydroxyproline 41 [93]

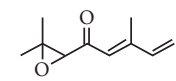

(E)-2(3)-Tagetenone epoxide 42 [91]<smiles>CC(=O)CC(C)C</smiles>

4-Methyl-2-pentanone 43 [3]

FIgURE 4: Continued. 
<smiles>CC1C=CC2CC1CC2(C)C</smiles>

$\alpha$-Pinene 44 [3-5, 123, 96, 97, 98, 99]<smiles>c1ccccc1</smiles>

1,3-5-Cycloheptatriene 45 [4]<smiles>CC1=CCC2(C)CC12</smiles>

(+)-2-Carene 46 [4]

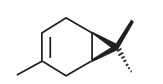

3-Carene 47 [4]

$\overbrace{\mathrm{H}_{3} \mathrm{C}}^{\mathrm{X}_{\mathrm{O}}^{\mathrm{CH}_{3}}}$

Eucalyptol 48 [4]<smiles>C=C(CC)CCCC(C)C</smiles>

1.8 myrcene 49 [123]

$\mathrm{H}_{2} \mathrm{C}>\mathrm{CH}_{\mathrm{CH}_{2}} \mathrm{CH}_{\mathrm{CH}_{3}}^{\mathrm{CH}_{3}}$

Ipsdienone 50 [123]

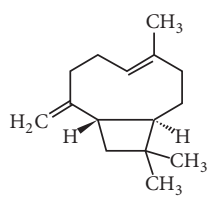

Caryophyllene 51 [93]

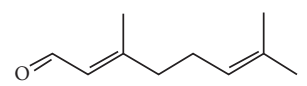

Geranial $\mathbf{5 2}[5,100,101]$

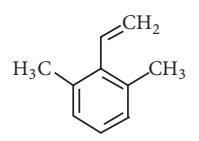

2,6-Dimethylstyrene 53 [100]<smiles>CC(C)=CCCC(C)=CCO</smiles>

Geraniol 54 [100]

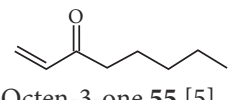

Octen-3-one 55 [5]

$\overbrace{\mathrm{H}_{3} \mathrm{C}}^{\mathrm{CH}_{3}}$

6-Methyl-5-hepten-2-one 56 [5]

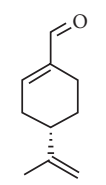

$\rho$-Mentha-1(7),8-diene 57 [5]

$$
\overbrace{\mathrm{H}_{3} \mathrm{C}}^{\mathrm{C}_{\mathrm{CH}_{3}}}
$$

Artemisia ketone 58 [5]

$\underset{\mathrm{H}_{3} \mathrm{C}}{\mathrm{H}_{2} \mathrm{C}} \underset{\mathrm{HO}_{\mathrm{CH}_{3}}}{\mathrm{CH}_{3}}$

Linalool oxide 59 [5]<smiles>CC1=CC[C@](N)(C(C)C)CC1</smiles>

Terpinen-4-ol 60 [5]

(Z)

(Z)- $\beta$-Ocimenone 61 [5]<smiles>C=CC(C)=CCC=C(C)C</smiles>

(E)- $\beta$-Ocimenone 62 [5]<smiles>C=C(C)C1CC=C(C)C(OC(C)=O)C1</smiles>

Carvyl acetate 63 [5]<smiles>CC1=CCC2(C1)C(C)CCC2C(C)C</smiles>
$\alpha$-Cubebene 64 [5]<smiles>CC(C)=CCC[C@H](C)C1CC=C(C)C1</smiles>

Sesquithujene 65 [5]

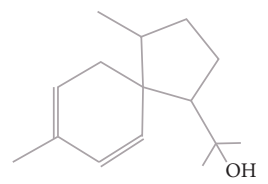

Acora-3,5-diene 66 [5]<smiles>C=C1CCC2CC1(C)C2CCC=C(C)C</smiles>

$\beta$-Bergamotene 67 [5]

Figure 4: Continued. 

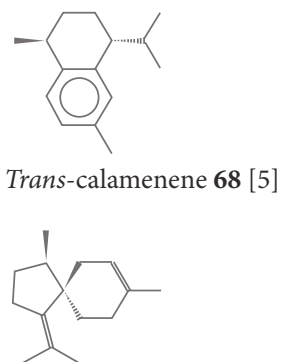

$\beta$-Alaskene 69<smiles>C=C1CCC(C(C)C)[C@]2(C)C=C(C)CC[C@H]12</smiles>

$\gamma$-Cadinene $70[45]$<smiles>CC1=CC23CCC(C)=C2CCC(C(C)C)C3C1</smiles>

$\delta$-Cadinene $71[3,96,97,99$

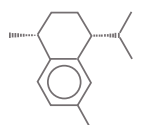

Cis-calamenene 72 [5]<smiles>C=CC(C)(O)CCC=C(C)CCC=C(C)C</smiles>

Nerolidol 73 [5]<smiles>C=CC(C)(O)CCC=C(C)CCC=C(C)C</smiles>

(E)-Nerolidol $74[3,96,97]$

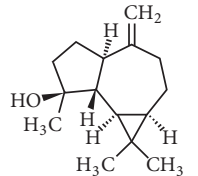

Spathulenol 75 [5]

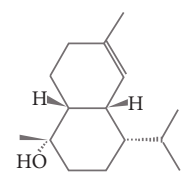

Epi- $\alpha$-muurolol 76 [5

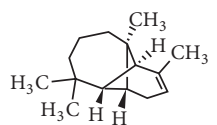

$\alpha$-Longipinene 77 [98]<smiles>CC1(C)C2CCCC1C2(C)C</smiles>

Chrysanthenone 78 [98]<smiles>CC1=CCC(C(C)(C)O)CC1</smiles>

$\alpha$-Terpineol $79[3,5,98,99]$

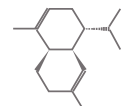

$\alpha$-Amorphene 80 [98]

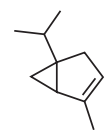

$\alpha$-Thujene 81 [99]<smiles>Cc1ccc(C)cc1</smiles>
$\gamma$-Terpinene 82 [99]<smiles>CC1=CCC2(CC1)C(C(C)C)CC[C@@H]2C</smiles>

$\alpha$-Cubebene 83 [99]<smiles>C=CC(C)(CCC=C(C)C)OC(C)=O</smiles>

Linalool acetate 84 [99]

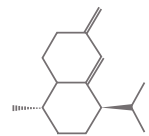

Bicyclosesquiphellandrene 85 [99]<smiles>C=C1C2CCC(C2)C1(C)C</smiles>

Camphene 86 [3, 5, 96, 97, 98, 99]

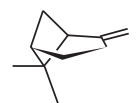

$\beta$-Pinene $87[3,5,99]$<smiles>C=C1CCC2(C(C)C)CC12</smiles>

Sabinene $\mathbf{8 8}[3,5,123,98,99]$<smiles>C=C(CC)CCC=C(C)C</smiles>

Myrcene 89 [3, 5, 123, 100, 101, 96, 97, 99, 102, 103]<smiles>CC1=CCC(C(C)C)C=C1</smiles>

$\alpha$-Phellandrene $90[3,5,96,97]$

Figure 4: Continued. 
${ }_{\mathrm{H}_{3} \mathrm{C}} \stackrel{\mathrm{O}}{\mathrm{O}} \overbrace{\mathrm{CH}_{3}}^{\mathrm{CH}_{3}}$

2-Methylbutyl isobutyrate 91 [3]

$\mathrm{H}_{2} \mathrm{C}_{\mathrm{CH}_{3}}^{\mathrm{CH}_{3}}$

Limonene 92 [3, 5, 100, 101, 96, 97, 98, 99, 102]

$\underbrace{\mathrm{C}_{\mathrm{C}}^{\mathrm{CH}}}_{\mathrm{H}_{3} \mathrm{C}}$

1,8-Cineole (=eucalyptol) 93 [3, 5, 98, 99, 103]

人

$\beta$-Phellandrene $94[3,4,96,97,99]$

(Z)-3-Hexenal 95 [3]

$\overbrace{\mathrm{CH}_{3}}^{\mathrm{CH}_{2}}$

(Z)- $\beta$-Ocimene $96[3,5,96,97,99]$

=

(E)- $\beta$-Ocimene 97 [3, 5, 96, 97, 99]

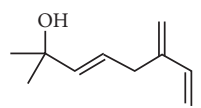

Isomyrcenol 98 [3]<smiles>Cc1ccc(C(C)C)cc1</smiles>

p-Cymene 99 [3, 5, 93, 96, 97, 98, 99]<smiles>CCC(C)COC(=O)C(C)CC</smiles>

2-Methylbutyl-2-methyl butyrate 100 [3]<smiles>CC1=CCC(C)=CC1</smiles>

Terpinolene 101 [3]

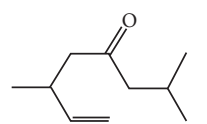

Dihydrotagetone $\mathbf{1 0 2}$ [3, 96, 97, 99, 103]

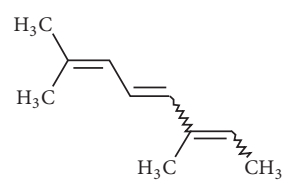

Cis-alloocimene 103 [3, 96, 97]
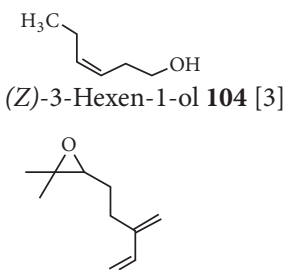

6,7-Epoxymyrcene 105 [3]

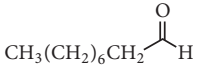

Nonanal 106 [3]

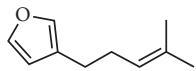

Perillene 107 [3, 99

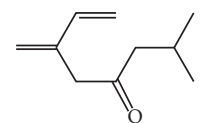

Ipsenone 108 [3, 123, 96, 97, 103]

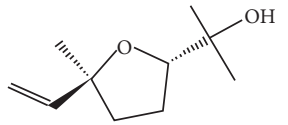

Trans-linalool oxide (furanoid) 109 [3, 96, 97, 98]<smiles>C=CCCCCCC</smiles>

1-Octen-3-ol $110[3,96,97]$<smiles>C1CC2CCOC2C1</smiles><smiles>CC1=CC1</smiles>

Cis-1,2-limonene epoxide 111 [3]<smiles>C1CCC2CC2C1</smiles>

齐

Trans-1,2-limonene epoxide 112 [3]

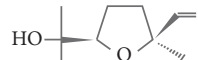

Cis-linalool oxide (furanoid) 113 [3, 96, 97, 98]

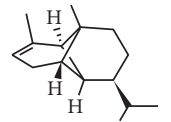

$\alpha$-Copaene $114[3,5,96,97,98]$

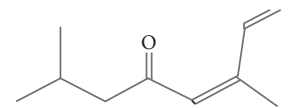

Cis-tagetone 115 [3, 96, 97]

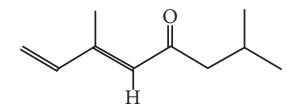

Trans-tagetone $116[3,96,97]$

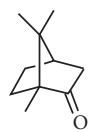

Camphor 117 [3, 5, 101, 96, 97, 98, 102]

Figure 4: Continued. 


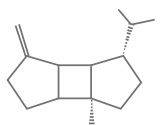

$\beta$-Bourbonene $118[3,5,99]$<smiles>O=Cc1ccccc1</smiles>

Benzaldehyde $119[3,5]$<smiles>C=CC(C)(O)CCC=C(C)C</smiles>

Linalool 120 [3, 5, 93, 100, 101, 96, 97, 98]<smiles>CC(C)=CCCC1(C)[C@H]2CC=C(C)[C@H]21</smiles>

Trans- $\alpha$-bergamotene 121 [3]

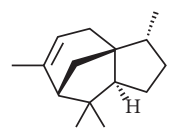

$\alpha$-Cedrene $122[3,5]$

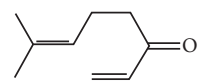

Myrcenone 123 [3, 5, 91, 99]<smiles>C=C1CC/C=C(/C)CCC2C1CC2(C)C</smiles>

$\beta$-Caryophyllene 124 [3, 5, 123, 101, 96, 97, 98, 99, 102]<smiles>C=CC(=C)C/C=C/C(C)(C)O</smiles>

2-Methyl-6-methylene-3,7-octadien-2-ol 125 [3]
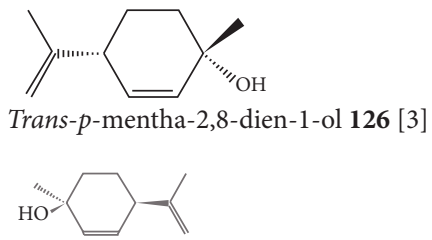

Cis-p-mentha-2,8-dien-1-ol 127 [3]

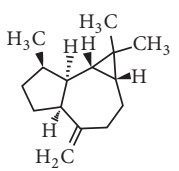

Alloaromadendrene 128 [3, 5, 96, 97]

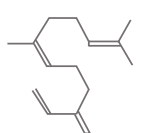

(Z)- $\beta$-Farnesene $129[3]$

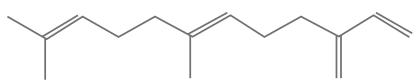

(E)- $\beta$-Farnesene $130[3,5]$
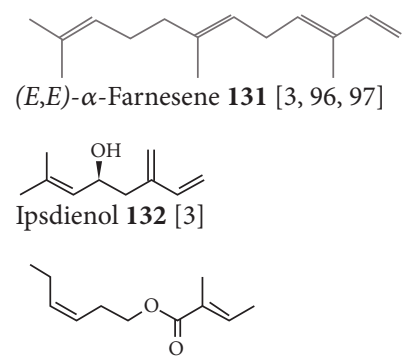

(Z)-3-Hexenyl tiglate 133 [3]
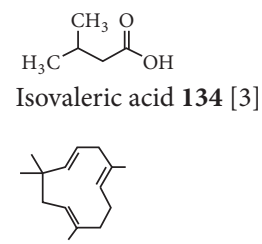

$\alpha$-Humulene 135 [3, 5, 96, 97, 99]

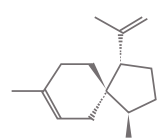

$\alpha$-Acoradiene 136 [3]

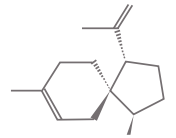

$\beta$-Acoradiene 137 [3]<smiles>C=C1CC[C@H](C(C)C)[C@H]2C=C(C)CC[C@H]12</smiles>

$\gamma$-Muurolene 138 [3, 5, 96, 97]<smiles>CC1=C[C@H]2C(C)=CC[C@H](C(C)C)[C@H]2CC1</smiles>

$\alpha$-Muurolene 139 [3, 5, 96, 97, 98]

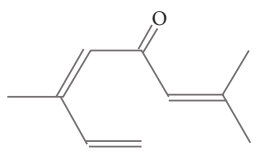

Cis-tagetenone 140 [3]

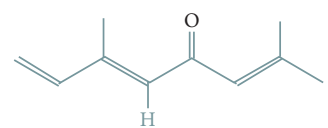

Trans-tagetenone 141 [3]<smiles>CC1(C)CCC2(C)CCC1C2O</smiles>

Borneol 142 [3, 5, 96, 97, 98]

FIgUre 4: Continued. 
<smiles>CCC1C(=O)CCC1(C)C</smiles>

Verbenone $143[3,99]$

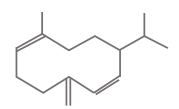

Germacrene-D 144 [3, 123, 101, 96, 97]

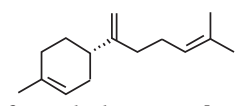

$\beta$-Bisabolene $145[3,5]$

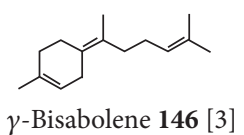

$\overbrace{\mathrm{O}}^{\mathrm{CH}_{2}}$

Trans-carvyl acetate 147 [3]<smiles>C=C(C)C1CC=C(C)C(=O)C1</smiles>

Carvone 148 [3, 5, 99]<smiles>CCCCC1CC2CC(C)CCCCC12</smiles>

Bicyclogermacrene $\mathbf{1 4 9}[3,5,96,97,99]$<smiles>CC(C)=CCC[C@H](C)C1=CCC(C)=CC1</smiles>

$\beta$-Curcumene 150 [3]<smiles>CC(C)=CCCC(C)c1ccc(C)cc1</smiles>

Ar-curcumene 151 [3]<smiles>CC1=CC(O)C(C(C)C)CC1</smiles>

Cis-piperitol 152 [3]<smiles>COC(=O)C=C(C)C</smiles>

2-Methyl-2-butenoic acid 153 [3]

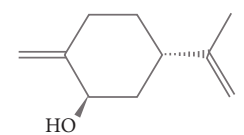

Trans-p-mentha-1(7),8-dien-2-ol 154 [3]<smiles>C=C1CCC(C(=C)C)CC1O</smiles>

Cis-p-mentha-1(7),8-dien-2-ol 155 [3]

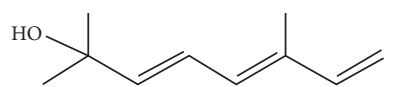

2,6-Dimethyl-3(E),5(E),7-octatriene-2-ol 156 [3, 96, 97]<smiles>C=C(C)[C@@H]1CC=C(C)[C@H](O)C1</smiles>

Trans-carveol 157 [3]<smiles>Cc1ccc2c(c1)C(C)CCC2C</smiles>

Calamenene 158 [3]

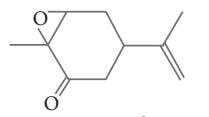

Carvone oxide 159 [3]<smiles>C=C(C)C1CCC(C)=CC1=O</smiles>

Isopiperitenone 160 [3]<smiles>C=C(C)[C@H]1CCC(C)=CC1=O</smiles>

Cis-carveol 161 [3]<smiles>CC1=CC(=O)C(=C(C)C)CC1</smiles>

Piperitenone 162 [2, 3, 91, 81]

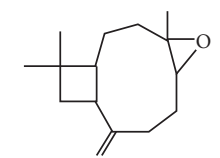

Isocaryophyllene oxide $\mathbf{1 6 3}[3,96,97]$

Figure 4: Continued. 
<smiles>C=C1CCC(C)C2CCCCC12C</smiles>

Caryophyllene oxide 164 [3-5, 96, 97, 98]

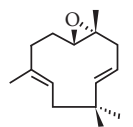

Humulene epoxide II 165 [3, 5, 96, 97]

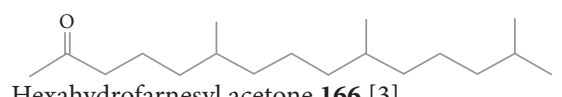

Hexahydrofarnesyl acetone 166 [3]

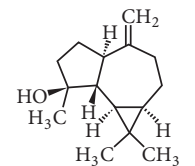

Spathulenol 167 [3]

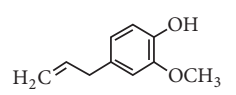

Eugenol $168[3,5]$

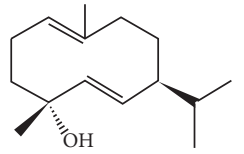

Germacrene-D-4-ol 169 [3]

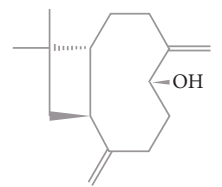

Caryophylla-2(12),6(13)-dien-5 $\beta$-ol (=Caryophylladienol I) 170 [3]

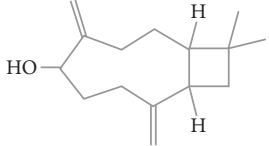

Caryophylla-2(12),6(13)-dien-5 $\alpha$-ol (=Caryophylladienol II) 171 [3]

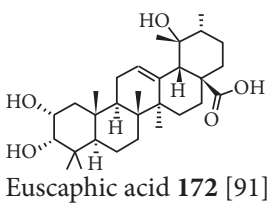

Figure 4

\section{Acknowledgments}

The author would like to express his gratitude to the National Research Foundation (NRF) and Govan Mbeki Research and Development Centre (GMRDC), University of Fort Hare, for financial support to conduct this research.

\section{References}

[1] J. W. Mwangi, I. Addae-Mensah, R. M. Munavu, and W. Lwande, "Essential oils of Kenyan Lippia species. Part III," Flavour and Fragrance Journal, vol. 6, no. 3, pp. 221-224, 1991.

[2] N. J. Manenzhe, N. Potgieter, and T. Van Ree, "Composition and antimicrobial activities of volatile components of Lippia javanica," Phytochemistry, vol. 65, no. 16, pp. 2333-2336, 2004.

[3] A. M. Viljoen, S. Subramoney, S. F. V. Vuuren, K. H. C. Başer, and B. Demirci, "The composition, geographical variation and antimicrobial activity of Lippia javanica (Verbenaceae) leaf essential oils," Journal of Ethnopharmacology, vol. 96, no. 1-2, pp. 271-277, 2005.

[4] N. Lukwa, P. Mølgaard, P. Furu, and C. Bøgh, "Lippia javanica (Burm. f.) Spreng: its general constituents and bioactivity on mosquitoes," Tropical Biomedicine, vol. 26, no. 1, pp. 85-91, 2009.
[5] L. S. Chagonda and J.-C. Chalchat, "Essential oil composition of Lippia javanica (Burm.f.) spreng chemotype from Western Zimbabwe," Journal of Essential Oil Bearing Plants, vol. 18, no. 2, pp. 482-485, 2015.

[6] W. Kipkore, B. Wanjohi, H. Rono, and G. Kigen, "A study of the medicinal plants used by the Marakwet Community in Kenya," Journal of Ethnobiology and Ethnomedicine, vol. 10, article 24, 2014.

[7] E. A. Shikanga, S. Combrinck, and T. Regnier, "South African Lippia herbal infusions: total phenolic content, antioxidant and antibacterial activities," South African Journal of Botany, vol. 76, no. 3, pp. 567-571, 2010.

[8] N. T. Parrant, "The potential of non-timber forest products of Botswana," Botswana Notes Records, vol. 28, no. 1, pp. 203-218, 1996.

[9] D. M. Motlhanka and S. W. Makhabu, "Medicinal and edible wild fruit plants of Botswana as emerging new crop opportunities," Journal of Medicinal Plants Research, vol. 5, no. 10, pp. 1836-1842, 2011.

[10] M. Bhebhe, T. N. Füller, B. Chipurura, and M. Muchuweti, "Effect of solvent type on total phenolic content and free radical scavenging activity of black tea and herbal infusions," Food Analytical Methods, vol. 9, no. 4, pp. 1060-1067, 2016. 
[11] M. Bhebhe, B. Chipurura, and M. Muchuweti, "Determination and comparison of phenolic compound content and antioxidant activity of selected local Zimbabwean herbal teas with exotic Aspalathus linearis," South African Journal of Botany, vol. 100, no. 1, pp. 213-218, 2015.

[12] B. Patiri and A. Borah, Wild Edible Plants of Assam, Geetakhi Printers, Guwahati, India, 2007.

[13] H. Narzary and A. Basumatary, "Proximate and vitamin C analysis of wild edible plants consumed by Bodos of Assam, India," Journal of Molecular Pathophysiology, vol. 4, no. 4, pp. 128-133, 2015.

[14] M. Gelfand, S. Mavi, R. B. Drummond, and B. Ndemera, The Traditional Medical Practitioners in Zimbabwe: His Principles of Practice and Pharmacopoeia, Mambo Press, Gweru, Zimbabwe, 1985.

[15] D. Davids, Materia medica and care: a study of the uses of medicinal herbs and remedies as a form of treatment and negotiating social relationships in cape town and surroundings [M.S. dissertation], University of the Western Cape, Cape Town, South Africa, 2012.

[16] A. Maroyi and G. K. E. Mosina, "Medicinal plants and traditional practices in peri-urban domestic gardens of the Limpopo province, South africa," Indian Journal of Traditional Knowledge, vol. 13, no. 4, pp. 665-672, 2014.

[17] A. Samie, C. L. Obi, P. O. Bessong, and L. Namrita, "Activity profiles of fourteen selected medicinal plants from Rural Venda communities in South Africa against fifteen clinical bacterial species," African Journal of Biotechnology, vol. 4, no. 12, pp. 1443-1451, 2005.

[18] T. York, An ethnopharmacological study of plants used for treating respiratory infections in rural Maputaland [M.S. dissertation], University of Zululand, KwaDlangezwa, South Africa, 2012.

[19] D. Davids, T. Blouws, O. Aboyade et al., "Traditional health practitioners' perceptions, herbal treatment and management of HIV and related opportunistic infections," Journal of Ethnobiology and Ethnomedicine, vol. 10, article 77, 2014.

[20] A. Hutchings, A. H. Scott, G. Lewis, and A. Cunningham, Zulu Medicinal Plants: An Inventory, University of Natal Press, Pietermarizburg, South Africa, 1996.

[21] R. M. Coopoosamy and K. K. Naidoo, "An ethnobotanical study of medicinal plants used by traditional healers in Durban, South Africa," African Journal of Pharmacy and Pharmacology, vol. 6, no. 11, pp. 818-823, 2012.

[22] I. Hedberg and F. Staugard, Traditional Medicinal Plants in Botswana, Ipeleng, Gaborone, Botswana, 1989.

[23] H. Shahriar, A. S. M. H. K. Chowdhury, S. Rahman et al., "Scientific validation of medicinal plants used by a folk medicinal practitioner of Chuadanga District, Bangladesh," World Journal of Pharmacy and Pharmaceutical Sciences, vol. 3, no. 11, pp. 1324, 2014.

[24] S. S. Semenya, M. J. Potgieter, and M. P. Tshisikhawe, "Use, conservation and present availability status of ethnomedicinal plants of Matebele-Village in the Limpopo Province, South Africa," African Journal of Biotechnology, vol. 12, no. 18, pp. 2392-2405, 2013.

[25] M. Roberts, Indigenous Healing Plants, Southern Book Publishers, Halfway House, Johannesburg, South Africa, 1990.

[26] T. Birhanu, D. Abera, and E. Ejeta, "Ethnobotanical study of medicinal plants in selected Horro Gudurru Woredas, western Ethiopia," Journal of Biology, Agriculture and Healthcare, vol. 5, no. 1, pp. 83-93, 2015.
[27] N. T. Mahlangeni, R. Moodley, and S. B. Jonnalagadda, "Elemental composition of Cyrtanthus obliquus and Lippia javanica used in South African herbal tonic, Imbiza," Arabian Journal of Chemistry, 2013.

[28] W. Musila, D. Kisangau, and J. Muema, "Conservation status and use of medicinal plants by traditional medical practitioners in Machakos District, Kenya," in Indigenous Knowledge Conference Proceedings, Pennsylvania State University, May 27-29 2004, 2004.

[29] G. N. Njoroge and R. W. Bussmann, “Traditional management of ear, nose and throat (ENT) diseases in Central Kenya," Journal of Ethnobiology and Ethnomedicine, vol. 2, article 54, 2006.

[30] P. Chigora, R. Masocha, and F. Mutenheri, “The role of indigenous medicinal knowledge (IMK) in the treatment of ailments in rural Zimbabwe: the case of Mutirikwi communal lands," Journal of Sustainable Development in Africa, vol. 9, no. 2, pp. 26-43, 2007.

[31] R. W. Bussmann, G. G. Gilbreath, J. Solio et al., "Plant use of the Maasai of Sekenani Valley, Maasai Mara, Kenya," Journal of Ethnobiology and Ethnomedicine, vol. 2, article 22, 2006.

[32] D. Motlhanka and G. P. Nthoiwa, "Ethnobotanical Survey of medicinal plants of Tswapong North, in Eastern Botswana: a case of plants from Mosweu and Seolwane Villages," European Journal of Medicinal Plants, vol. 3, no. 1, pp. 10-24, 2013.

[33] A. Vhurumuku, "Knowledge, use and attitudes towards medicinal plants of pre-service teachers at a South African University," Global Advanced Research Journal in Environmental Science and Toxicology, vol. 4, no. 2, pp. 15-24, 2015.

[34] M. N. Nkwanyana, An ethnobotanical and antidiarrhoeal investigation of plants used traditionally in the maputaland area homesteads [M.S. dissertation], University of Zululand, KwaDlangezwa, South Africa, 2013.

[35] T. E. Moeng, An investigation into the trade of medicinal plants by muthi shops and street vendors in the Limpopo Province, South Africa [M.S. thesis], University of Limpopo, Gauteng, South Africa, 2010.

[36] S. Bandeira, A. M. Manjate, and O. Filipe, "An Ecological Assessment of the Health of the Chibuto-Missavene Wetland in the Dry Season, Mozambique: Emphasis on Resources Assessment, Utilization and Sustainability Analysis," report to Challenge Program for Water and Food, International Water Management Institute, Pretoria, South Africa, 2006, https://cgspace.cgiar.org/bitstream/handle/10568/21604/21604 .pdf? sequence $=1$.

[37] M. C. Palgrave, R. B. Drummond, and E. J. Moll, Trees of Southern Africa, Struik, Cape Town, South Africa, 2003.

[38] M. O. Nanyingi, J. M. Mbaria, A. L. Lanyasunya et al., "Ethnopharmacological survey of Samburu district, Kenya," Journal of Ethnobiology and Ethnomedicine, vol. 4, article 14, 2008.

[39] J. G. J. P. Sankar and K. B. Satapathy, "Weed diversity of Rabi crops and their ethnomedicinal uses in Kendrapara district of Odisha, India," International Research Journal of Biological Sciences, vol. 4, no. 3, pp. 33-38, 2015.

[40] D. E. N. Mabogo, The ethnobotany of the vhavenda [M.S. dissertation], University of Pretoria, Pretoria, South Africa, 1990.

[41] B.-E. van Wyk, B. van Oudtshoorn, and N. Gericke, Medicinal Plants of South Africa, Briza, Pretoria, South Africa, 2013.

[42] S. S. Semenya and A. Maroyi, "Medicinal plants used for the treatment of tuberculosis by Bapedi traditional healers 
in three districts of the Limpopo Province, South Africa," African Journal of Traditional, Complementary, and Alternative Medicine, vol. 10, no. 2, pp. 316-323, 2013.

[43] L. Bunalema, S. Obakiro, J. R. S. Tabuti, and P. Waako, "Knowledge on plants used traditionally in the treatment of tuberculosis in Uganda," Journal of Ethnopharmacology, vol. 151, no. 2, pp. 999-1004, 2014.

[44] P. Bruschi, M. Morganti, M. Mancini, and M. A. Signorini, "Traditional healers and laypeople: a qualitative and quantitative approach to local knowledge on medicinal plants in Muda (Mozambique)," Journal of Ethnopharmacology, vol. 138, no. 2, pp. 543-563, 2011.

[45] A. T. Bryant, Zulu Medicine and Medicine-Men, C. Struik, Cape Town, South Africa, 1966.

[46] N. S. Mkarafuu, The role of non wood forest products in improving livelihoods of communities surrounding Jozani and Chwaka Bay National Park, Zanzibar [M.S. thesis], Sokoine University of Agriculture, Morogoro, Tanzania, 2010.

[47] S. Kumar and D. Dash, "Flora of Nandan Kanan sanctuary: medicinal plants with their role in health care," International Journal of Pharmacy and Life Sciences, vol. 3, no. 4, pp. 16311642, 2012.

[48] N. Lukwa, N. Z. Nyazema, C. F. Curtis, G. L. Mwaiko, and S. K. Chandiwana, "People's perceptions about malaria transmission and control using mosquito repellent plants in a locality in Zimbabwe," Central African Journal of Medicine, vol. 45, no. 3, pp. 64-68, 1999.

[49] E. J. Mavundza, R. Maharaj, J. F. Finnie, G. Kabera, and J. van Staden, "An ethnobotanical survey of mosquito repellent plants in uMkhanyakude district, KwaZulu-Natal province, South Africa," Journal of Ethnopharmacology, vol. 137, no. 3, pp. 15161520, 2011.

[50] J. Mahachi, Medicinal properties of some plants used for the treatment of skin disorders in the OR Tambo and Amathole municipalities of the Eastern Cape Province, South Africa [M.S. dissertation], Walter Sisulu University, Mthatha, South Africa, 2013.

[51] M. M. Matlebyane, J. W. W. Ngambi, and E. M. Aregheore, "Indigenous knowledge (IK) ranking of available browse and grass species and some shrubs used in medicinal and ethno-veterinary practices in ruminant livestock production in Limpopo province, South Africa," Livestock Research for Rural Development, vol. 22, no. 3, p. 54, 2010.

[52] S. O. Bandeira, F. Gaspar, and F. P. Pagula, "African ethnobotany and healthcare: Emphasis on Mozambique," Pharmaceutical Biology, vol. 39, pp. 70-73, 2001.

[53] C. A. Liengme, "Plants used by the Tsonga people of Gazankulu," Bothalia, vol. 13, no. 3-4, pp. 501-518, 1981.

[54] A. J. Afolayan, D. S. Grierson, and W. O. Mbeng, "Ethnobotanical survey of medicinal plants used in the management of skin disorders among the Xhosa communities of the Amathole District, Eastern Cape, South Africa," Journal of Ethnopharmacology, vol. 153, no. 1, pp. 220-232, 2014.

[55] O. O. G. Amusan, N. A. Sukati, and M. S. Shongwe, "Some phytomedicines from Shiselweni region of Swaziland," Journal of Natural Remedies, vol. 5, no. 1, pp. 19-25, 2005.

[56] H. de Wet, S. Nciki, and S. F. van Vuuren, "Medicinal plants used for the treatment of various skin disorders by a rural community in northern Maputaland, South Africa," Journal of Ethnobiology and Ethnomedicine, vol. 9, article 51, 2013.

[57] O. Amuka, P. O. Okemo, A. K. Machocho, and P. K. Mbugua, "Ethnobotanical survey of selected medicinal plants used by
Ogiek communities in Kenya against microbial infections," Ethnobotany Research and Applications, vol. 12, pp. 627-641, 2014.

[58] A. Hutchings, "Ritual cleansing, incense and the tree of life: observations on some indigenous plant usage in traditional Zulu and Xhosa purification and burial rites," Alternation, vol. 14, no. 2, pp. 189-218, 2007.

[59] E. T. Nyahangare, B. M. Mvumi, and T. Mutibvu, "Ethnoveterinary plants and practices used for ecto-parasite control in semi-arid smallholder farming areas of Zimbabwe," Journal of Ethnobiology and Ethnomedicine, vol. 11, article 30, 2015.

[60] E. T. Nyahangare, B. M. Mvumi, and P. C. Stevenson, "Tick control measures from nature," Afgriland, vol. 56, no. 3, pp. 7677, 2012.

[61] V. L. Narayana and G. M. Narasimharao, "Plants used in ethnoveterinary medicine by tribals of Visakhapatnam and Vizianagarm districts, Andhra Pradesh, India," International Journal of Pure and Applied Bioscience, vol. 3, no. 2, pp. 432-439, 2015.

[62] C. A. Onyango, L. W. Gakuya, F. M. Mathooko et al., "Preservative effect of various indigenous plants on fermented milk from Maasai community of Kajiado County," Journal of Applied Biosciences, vol. 73, pp. 5935-5941, 2014.

[63] I. T. Rampedi, Indigenous plants in the Limpopo Province: potential for their commercial beverage production [Ph.D. thesis], University of South Africa, Pretoria, South Africa, 2010.

[64] N. Lukwa, "Do traditional mosquito repellent plants work as mosquito larvicides?" Central African Journal of Medicine, vol. 40, no. 11, pp. 306-309, 1994.

[65] United Nations Programme on HIV/AIDS, "AIDS epidemic update: Special Report on HIV/AIDS,” 2006, http://data.unaids .org/pub/EpiReport/2006/2006_EpiUpdate_en.pdf.

[66] A. R. Ndhlala, G. I. Stafford, J. F. Finnie, and J. van Staden, "In vitro pharmacological effects of manufactured herbal concoctions used in KwaZulu-Natal, South Africa," Journal of Ethnopharmacology, vol. 122, no. 1, pp. 117-122, 2009.

[67] O. O. G. Amusan, P. S. Dlamini, J. D. Msonthi, and L. P. Makhubu, "Some herbal remedies from Manzini region of Swaziland," Journal of Ethnopharmacology, vol. 79, no. 1, pp. 109-112, 2002.

[68] J. Williamson, Useful Plants of Malawi, University of Malawi, Limbe, Cameroon, 1974.

[69] C. K. Kaingu, J. A. Oduma, and T. I. Kanui, "Practices of traditional birth attendants in Machakos District, Kenya," Journal of Ethnopharmacology, vol. 137, no. 1, pp. 495-502, 2011.

[70] C. M. Doke and B. W. Vilakazi, Zulu-English Dictionary, Witwatersrand University Press, Johannesburg, South Africa, 1972.

[71] O. O. Amusan, "Herbal medicine in Swaziland: an overview," in African Natural Plant Products: New Discoveries and Challenges in Chemistry and Quality, vol. 1021 of ACS Symposium Series, pp. 31-49, American Chemical Society, Washington, DC, USA, 2010.

[72] O. O. G. Amusan, "Ethical and environmental issues in bioprospecting for drugs through traditional medicine: the case of Swaziland," The African Journal of Plant Sciences and Biotechnology, vol. 2, no. 1, pp. 1-9, 2008.

[73] A. Samie, A. Housein, N. Lall, and J. J. M. Meyer, "Crude extracts of, and purified compounds from, Pterocarpus angolensis, and the essential oil of Lippia javanica: their in-vitro cytotoxicities 
and activities against selected bacteria and Entamoeba histolytica," Annals of Tropical Medicine and Parasitology, vol. 103, no. 5, pp. 427-439, 2009.

[74] I. E. Cock and S. F. van Vuuren, "Anti-proteus activity of some South African medicinal plants: their potential for the prevention of rheumatoid arthritis," Inflammopharmacology, vol. 22, no. 1, pp. 23-36, 2014.

[75] M. A. Lekganyane, T. M. Matsebatlela, R. L. Howard, L. J. Shai, and P. Masoko, "The phytochemical, antibacterial and antioxidant activity of five medicinal plants against the wound infecting bacteria," African Journal of Biotechnology, vol. 11, no. 68, pp. 13210-13219, 2012.

[76] K. M. Thembo, H. F. Vismer, N. Z. Nyazema, W. C. A. Gelderblom, and D. R. Katerere, "Antifungal activity of four weedy plant extracts against selected mycotoxigenic fungi," Journal of Applied Microbiology, vol. 109, no. 4, pp. 1479-1486, 2010.

[77] P. Masoko and K. M. Nxumalo, "Validation of antimycobacterial plants used by traditional healers in three districts of the Limpopo Province (South Africa)," Evidence-based Complementary and Alternative Medicine, vol. 2013, Article ID 586247, 7 pages, 2013.

[78] D. R. Katerere, G. Graziani, K. M. Thembo, N. Z. Nyazema, and A. Ritieni, "Antioxidant activity of some African medicinal and dietary leafy African vegetables," African Journal of Biotechnology, vol. 11, no. 17, pp. 4103-4108, 2012.

[79] T. A. Ayuko, R. N. Njau, W. Cornelius, N. Leah, and I. O. Ndiege, "In vitro antiplasmodial activity and toxicity assessment of plant extracts used in traditional malaria therapy in the Lake Victoria Region," Memórias do Instituto Oswaldo Cruz, vol. 104, no. 5, pp. 689-694, 2009.

[80] C. Clarkson, V. J. Maharaj, N. R. Crouch et al., "In vitro antiplasmodial activity of medicinal plants native to or naturalised in South Africa," Journal of Ethnopharmacology, vol. 92, no. 2-3, pp. 177-191, 2004.

[81] D. K. Olivier, E. A. Shikanga, S. Combrinck, R. W. M. Krause, T. Regnier, and T. P. Dlamini, "Phenylethanoid glycosides from Lippia javanica," South African Journal of Botany, vol. 76, no. 1, pp. 58-63, 2010.

[82] H. Rimpler and H. Sauerbier, "Iridoid glucosides as taxonomic markers in the genera Lantana, Lippia, Aloysia and Phyla," Biochemical Systematics and Ecology, vol. 14, no. 3, pp. 307-310, 1986.

[83] S. F. Mujovo, A. A. Hussein, J. J. M. Meyer, B. Fourie, T. Muthivhi, and N. Lall, "Bioactive compounds from Lippia javanica and Hoslundia opposita," Natural Product Research, vol. 22, no. 12, pp. 1047-1054, 2008.

[84] M. T. Ludere, T. van Ree, and R. Vleggaar, "Isolation and relative stereochemistry of lippialactone, a new antimalarial compound from Lippia javanica," Fitoterapia, vol. 86, no. 3, pp. 188-192, 2013.

[85] R. Neidlein and R. Staehle, "Constituents of Lippia javanica. III," Deutsche Apotheker Zeitung, vol. 40, pp. 1588-1592, 1974.

[86] T. P. Dlamini, Isolation and characterization of bioactive compounds from Lippia javanica [M.S. thesis], University of Johannesburg, Johannesburg, South Africa, 2006.

[87] R. Sõukand and R. Kalle, "Where does the border lie: locally grown plants used for making tea for recreation and/or healing, 1970s-1990s Estonia," Journal of Ethnopharmacology, vol. 150, no. 1, pp. 162-174, 2013.

[88] Y. Frum and A. M. Viljoen, "In vitro 5-lipoxygenase and antioxidant activities of South African medicinal plants commonly used topically for skin diseases," Skin Pharmacology and Physiology, vol. 19, no. 6, pp. 329-335, 2006.

[89] S. F. van Vuuren, The antimicrobial activity and essential oil composition of medicinal aromatic plants used in african traditional healing [Ph.D. thesis], University of the Witwatersrand, Johannesburg, South Africa, 2007.

[90] S. Suliman, Antimicrobial interactions of Artemisia afra used in african traditional medicine [M.S. dissertation], University of the Witwatersrand, Johannesburg, South Africa, 2011.

[91] S. Virijevic, Antimicrobial and chemical properties of essential oils from indigenous South African lippia species [M.S. dissertation], Tshwane University of Technology, Tshwane, South Africa, 2012.

[92] L. S. Chagonda, C. D. Makanda, and J.-C. Chalchat, "Essential oils of wild and cultivated Lippia javanica (Spreng) and L. oatesii(Rolfe) from Zimbabwe," Journal of Essential Oil Research, vol. 12, no. 1, pp. 1-6, 2000.

[93] O. Ngassapa, D. K. B. Runyoro, E. Harvala, and I. B. Chinou, "Composition and antimicrobial activity of essential oils of two populations of Tanzanian Lippia javanica (Burm. f.) Spreng. (Verbenaceae)," Flavour and Fragrance Journal, vol. 18, no. 3, pp. 221-224, 2003.

[94] O. Amuka, A. K. Machocho, P. O. Okemo, and P. K. Mbugua, "Antibacterial and antifungal activities of essential oils from Satureia biflora D. Don, Benth, Speng (Chepsagitiet), Lippia javanica Burm. f. (Labotuet) and Toddalia asiatica (L) Lam. Rutaceae (Chepindoruet)," Global Journal of Science Frontier Research: B Chemistry, vol. 14, no. 4, pp. 45-51, 2014.

[95] S. R. Magano, F. Nchu, and J. N. Eloff, "In vitro investigation of the repellent effects of the essential oil of Lippia javanica on adults of Hyalomma marginatum rufipes," African Journal of Biotechnology, vol. 10, no. 44, pp. 8970-8975, 2011.

[96] A. Hutchings and J. van Staden, "Plants used for stress-related ailments in traditional Zulu, Xhosa and Sotho medicine. Part 1: plants used for headaches," Journal of Ethnopharmacology, vol. 43, no. 2, pp. 89-124, 1994.

[97] H. E. Marx, N. O’Leary, Y.-W. Yuan et al., "A molecular phylogeny and classification of Verbenaceae," American Journal of Botany, vol. 97, no. 10, pp. 1647-1663, 2010.

[98] A. A. Munir, "A taxonomic revision of the genus Lippia (Houst. ex) Linn. (Verbenaceae) in Australia," Journal of the Adelaide Botanic Garden, vol. 15, no. 2, pp. 129-145, 1993.

[99] R. W. Sanders, "The genera of Verbenaceae in the southeastern United States," Harvard Papers in Botany, vol. 5, no. 2, pp. 303358, 2001.

[100] J. M. S. de Campos, S. M. Sousa, P. S. Silva, L. C. Pinheiro, F. Sampaio, and L. F. Viccini, "Chromosome numbers and DNA C values in the genus Lippia (Verbenaceae)," Plant Systematics and Evolution, vol. 291, no. 1, pp. 133-140, 2011.

[101] B. Verdcourt, "Verbenaceae," in Flora of Tropical Africa, R. M. Polhill, Ed., p. 155, A. A Balkema, Rotterdam, The Netherlands, 1992.

[102] M. Hyde, B. Wursten, P. Ballings, and M. C. Palgrave, "Flora of Zimbabwe: species information: Lippia javanica (Burm. f.) Spreng," http://www.zimbabweflora.co.zw/speciesdata/species .php?species_id=148720.

[103] IPNI (International Plant Name Index), 2016, http://www.ipni .org.

[104] H. H. W. Pearson, "Verbenaceae," Flora Capensis, vol. 5, no. 3, pp. 192-197, 1912. 
[105] B.-E. van Wyk and N. Gericke, People's Plants: A Guide to Useful Plants of Southern Africa, Briza, Pretoria, South Africa, 2000.

[106] R. Fernandes, "Verbenaceae," in Flora Zambesiaca, G. V. Pope and E. S. Martins, Eds., vol. 8, part 7, pp. 6-61, Royal Botanic Gardens, London, UK, 2005.

[107] B.-E. Van Wyk, "The potential of South African plants in the development of new food and beverage products," South African Journal of Botany, vol. 77, no. 4, pp. 857-868, 2011.

[108] H. R. Juliani, Y. Koelliker, M. Bucuk et al., "Quality and consumer studies in the USA of African herbal teas for the natural product industry development in sub-Sahara Africa," in Proceedings of the African Natural Plant Products: New Discoveries and Challenges in Chemistry and Quality Symposium, H. R. Juliani, J. E. Simon, and C.-T. Ito, Eds., vol. 1021 of ACS Symposium Series, pp. 403-420, American Chemical Society Publications, Washington, DC, USA, 2009.

[109] C. Pretorious, Antioxidant properties of Lippia javanica (Burm. f.) Spreng [M.S. thesis], North West University, Potchefstroom, South Africa, 2010.

[110] M. Whiteside, Encouraging Sustainable Family Sector Agriculture in Botswana, Cooperation for Research, Development and Education (CORDE), Gaborone, Botswana, 1997.

[111] B.-E. Van Wyk, "A broad review of commercially important southern African medicinal plants," Journal of Ethnopharmacology, vol. 119, no. 3, pp. 342-355, 2008.

[112] H. Wild and M. Gelfand, "Some native herbal remedies at present in use in Mashonaland," The Central African journal of medicine, vol. 5, no. 6, pp. 292-305, 1959.

[113] G. N. Njoroge and J. W. Kibunga, "Herbal medicine acceptance, sources and utilization for diarrhoea management in a cosmopolitan urban area (Thika, Kenya)," African Journal of Ecology, vol. 45, no. 1, pp. 65-70, 2007.

[114] A. Ribeiro, M. M. Romeiras, J. Tavares, and M. T. Faria, "Ethnobotanical survey in Canhane village, district of Massingir, Mozambique: medicinal plants and traditional knowledge," Journal of Ethnobiology and Ethnomedicine, vol. 6, article 33, 2010.

[115] S. S. Semenya and A. Maroyi, "Medicinal plants used by the Bapedi traditional healers to treat diarrhoea in the Limpopo Province, South Africa," Journal of Ethnopharmacology, vol. 144, no. 2, pp. 395-401, 2012.

[116] A. Maroyi, "Traditional use of medicinal plants in south-central Zimbabwe: review and perspectives," Journal of Ethnobiology and Ethnomedicine, vol. 9, article 31, 2013.

[117] V. J. Maharaj, G. Fouche, J. Senabe, R. Nthambeleni, and F. Kotze, "Agro-processing opportunities identified through a novel mosquito repellent from a medicinal plant," in Proceedings of the 2nd CSIR Biennial Conference on Science Real and Relevant, Pretoria, South Africa, November 2008, http://hdl.handle.net.

[118] J. McCosh, Z. Nxele, B. Letty, E. de Beer, N. Majara, and K. Swanepoel, "Study to develop a strategy for the development of a viable essential oils industry in South Africa: review and situation analysis," INR Report 442/11, Institute of Natural Resources, Pietermaritzburg, South Africa, 2011.

[119] CSIR (Council for Scientific and Industrial Research), CSIR patent, mosquito repellent, South African patent no. 95/9583, 1995.

[120] J. Madzimure, E. T. Nyahangare, H. Hamudikuwanda et al., "Acaricidal efficacy against cattle ticks and acute oral toxicity of Lippia javanica (Burm F.) Spreng," Tropical Animal Health and Production, vol. 43, no. 2, pp. 481-489, 2011.
[121] Q. Hou, W.-J. He, H.-J. Hao et al., "The four-herb chinese medicine ANBP enhances wound healing and inhibits scar formation via bidirectional regulation of transformation growth factor pathway," PLoS ONE, vol. 9, no. 12, Article ID e112274, 2014.

[122] E.-M. M. Abubakar, "The use of Psidium guajava Linn. in treating wound, skin and soft tissue infections," Scientific Research and Essays, vol. 4, no. 6, pp. 605-611, 2009.

[123] N. N. Mokoka, Indigenous knowledge of fever tea (Lippia javanica) and effect of shade netting on plant growth, oil yield and compound composition [M.S. thesis], University of Pretoria, Pretoria, South Africa, 2005.

[124] M. A. Ngwenya, A. Koopman, and R. Williams, Zulu Botanical Knowledge: An Introduction, National Botanical Institute, Pretoria, South Africa, 2003.

[125] M. Muchuweti, L. Nyamukonda, L. S. Chagonda, A. R. Ndhlala, C. Mupure, and M. Benhura, "Total phenolic content and antioxidant activity in selected medicinal plants of Zimbabwe," International Journal of Food Science and Technology, vol. 41, no. 1, pp. 33-38, 2006.

[126] E. Shikanga, T. Regnier, S. Combrinck, and B. Botha, "Polar Lippia extracts as alternatives for the postharvest control of Guazatine ${ }^{\circledR}$-resistant strains of Penicillium digitatum in citrus," Fruits, vol. 64, no. 2, pp. 75-82, 2009.

[127] M. Sandasi, G. P. P. Kamatou, S. Combrinck, and A. M. Viljoen, "A chemotaxonomic assessment of four indigenous South African Lippia species using GC-MS and vibrational spectroscopy of the essential oils," Biochemical Systematics and Ecology, vol. 51, no. 3, pp. 142-152, 2013.

[128] S. Sedaghathoor, A. M. Torkashvand, D. Hashemabadi, and B. Kaviani, "Yield and quality response of tea plant to fertilizers," African Journal of Agricultural Research, vol. 4, no. 6, pp. 568570, 2009.

[129] K. O. Soetan, C. O. Olaiya, and O. E. Oyewole, “The importance of mineral elements for humans, domestic animals and plants: a review," African Journal of Food Science, vol. 4, no. 5, pp. 200 222, 2008.

[130] R. Borneo, A. E. León, A. Aguirre, P. Ribotta, and J. J. Cantero, "Antioxidant capacity of medicinal plants from the Province of Córdoba (Argentina) and their in vitro testing in a model food system," Food Chemistry, vol. 112, no. 3, pp. 664-670, 2009.

[131] W.-Y. Huang, Y.-Z. Cai, and Y. Zhang, "Natural phenolic compounds from medicinal herbs and dietary plants: potential use for cancer prevention," Nutrition and Cancer, vol. 62, no. 1, pp. 1-20, 2010.

[132] A. Djilani and A. Dicko, "The therapeutic benefits of essential oils, nutrition, well-being and health," 2012, http://www.intechopen.com/books/nutrition-well-being-and-health/the-therapeutic-benefits-of-essential-oils.

[133] S. Kumar and A. K. Pandey, "Chemistry and biological activities of flavonoids: an overview," The Scientific World Journal, vol. 2013, Article ID 162750, 16 pages, 2013.

[134] T. P. T. Cushnie and A. J. Lamb, "Antimicrobial activity of flavonoids," International Journal of Antimicrobial Agents, vol. 26, no. 5, pp. 343-356, 2005.

[135] A. Tapas, D. Sakarkar, and R. Kakde, "Flavonoids as nutraceuticals: a review," Tropical Journal of Pharmaceutical Research, vol. 7, no. 3, pp. 1089-1099, 2008.

[136] Y. Nishizuka, "The molecular heterogeneity of protein kinase $C$ and its implications for cellular regulation," Nature, vol. 334, no. 6184, pp. 661-665, 1988. 
[137] T. Hunter, "Protein kinases and phosphatases: the Yin and Yang of protein phosphorylation and signaling," Cell, vol. 80 , no. 2 , pp. 225-236, 1995.

[138] J. W. Critchfield, S. T. Butera, and T. M. Folks, "Inhibition of HIV activation in latently infected cells by flavonoid compounds," AIDS Research and Human Retroviruses, vol. 12, no. 1, pp. 3946, 1996.

[139] T. Kamiya, "Biological functions and health benefits of amino acids," Food Fermentation Journal Japan, vol. 206, pp. 33-44, 2002.

[140] G. Fouche, G. M. Cragg, P. Pillay, N. Kolesnikova, V. J. Maharaj, and J. Senabe, "In vitro anticancer screening of South African plants," Journal of Ethnopharmacology, vol. 119, no. 3, pp. 455461, 2008.

[141] W. M. Arika, Y. A. Abdirahman, M. M. Mawia et al., "Hypoglycemic effect of Lippia javanica in alloxan induced diabetic mice," Journal of Diabetes Metabolism, vol. 6, article 624, 2015.

[142] J. Govere, D. N. Durrheim, N. du Toit, R. H. Hunt, and M. Coetzee, "Local plants as repellents against Anopheles arabiensis, in Mpumalanga Province, South Africa," Central African Journal of Medicine, vol. 46, no. 8, pp. 213-216, 2000.

[143] A. Samie, T. Tambani, E. Harshfield, E. Green, J. N. Ramalivhana, and P. O. Bessong, "Antifungal activities of selected venda medicinal plants against candida albicans, Candida krusei and cryptococcus neoformans isolated from South African AIDS patients," African Journal of Biotechnology, vol. 9, no. 20, pp. 2965-2976, 2010.

[144] E. A. Prozesky, J. J. M. Meyer, and A. I. Louw, "In vitro antiplasmodial activity and cytotoxicity of ethnobotanically selected South African plants," Journal of Ethnopharmacology, vol. 76, no. 3, pp. 239-245, 2001.

[145] M. O. Omolo, D. Okinyo, I. O. Ndiege, W. Lwande, and A. Hassanali, "Fumigant toxicity of the essential oils of some African plants against Anopheles gambiae sensu stricto," Phytomedicine, vol. 12, no. 3, pp. 241-246, 2005.

[146] L. J. McGaw, A. K. Jäger, and J. van Staden, "Antibacterial, anthelmintic and anti-amoebic activity in South African medicinal plants," Journal of Ethnopharmacology, vol. 72, no. 1-2, pp. 247-263, 2000.

[147] C. A. T. Katsvanga and S. Chigwiza, "Effectiveness of natural herbs, fever tea (Lippia javanica) and mexican marigold (Tagetes minuta) as substitutes to synthetic pesticides in controlling aphid species (Brevicoryne brassica) on cabbage (Brassica capitata)," Tropical and Subtropical Agroecosystems, vol. 4, no. 3, pp. 101-106, 2004.

[148] P. W. Mashela, H. A. Shimelis, D. de Waele, M. N. Mokgalong, F. N. Mudau, and L. G. Ngobeni, "Fever tea (Lippia javanica) as a root-knot nematode suppressant in tomato production," African Plant Protection, vol. 16, no. 1, pp. 1-6, 2010.

[149] L. Chikukura, B. M. Mvumi, R. Chikonzo, and C. Chenzara, "Evaluation of selected indigenous pesticidal plant powders against stored maize and cowpeas insect pests," in Proceedings of the African Crop Science Conference, vol. 10, pp. 191-194, 2011.

[150] S. Muzemu, B. M. Mvumi, S. P. M. Nyirenda et al., "Pesticidal effects of indigenous plants extracts against rape aphids and tomato red spider mites," in Proceedings of the African Crop Science Conference Proceedings, vol. 10, pp. 169-171, 2012.

[151] D. W. Nyamai, W. Arika, P. E. Ogola, E. N. M. Njagi, and M. P. Ngugi, "Medicinally important phytochemicals: an untapped research evenue," Research and Reviews: Journal of Pharmacognosy and Phytochemistry, vol. 4, no. 1, pp. 35-49, 2016.
[152] C. S. Yang, J. M. Landau, M.-T. Huang, and H. L. Newmark, "Inhibition of carcinogenesis by dietary polyphenolic compounds," Annual Review of Nutrition, vol. 21, pp. 381-406, 2001.

[153] A. Salminen, M. Lehtonen, T. Suuronen, K. Kaarniranta, and J. Huuskonen, "Terpenoids: natural inhibitors of NF- $\kappa$ B signaling with anti-inflammatory and anticancer potential," Cellular and Molecular Life Sciences, vol. 65, no. 19, pp. 2979-2999, 2008.

[154] E. J. Mavundza, R. Maharaj, J. C. Chukwujekwu, J. F. Finnie, and J. Van Staden, "Screening for adulticidal activity against Anopheles arabiensis in ten plants used as mosquito repellent in South Africa," Malaria Journal, vol. 13, article 173, 2014.

[155] S. Chanda and R. Dave, "In vitro models for antioxidant activity evaluation and some medicinal plants possessing antioxidant properties: an overview," African Journal of Microbiology Research, vol. 3, no. 13, pp. 981-996, 2009.

[156] K. Knobloch, A. Pauli, B. Iberl, H. Weigand, and N. Weis, "Antibacterial and antifungal properties of essential oil components," Journal of Essential Oil Research, vol. 1, no. 3, pp. 119-128, 1989.

[157] J. B. Hinou, C. E. Harvala, and E. B. Hinou, "Antimicrobial activity screening of 32 common constituents of essential oils," Pharmazie, vol. 44, no. 4, pp. 302-303, 1989.

[158] J. Kim, M. R. Marshall, and C.-I. Wei, "Antibacterial activity of some essential oil components against five foodborne pathogens," Journal of Agricultural and Food Chemistry, vol. 43, no. 11, pp. 2839-2845, 1995.

[159] S. Pattnaik, V. R. Subramanyam, M. Bapaji, and C. R. Kole, "Antibacterial and antifungal activity of aromatic constituents of essential oils," Microbios, vol. 89, no. 358, pp. 39-46, 1997.

[160] S. Gibbons, "Anti-staphylococcal plant natural products," Natural Product Reports, vol. 21, no. 2, pp. 263-277, 2004.

[161] N. D. Martini, D. R. P. Katerere, and J. N. Eloff, "Biological activity of five antibacterial flavonoids from Combretum erythrophyllum (Combretaceae)," Journal of Ethnopharmacology, vol. 93, no. 2-3, pp. 207-212, 2004.

[162] A. Basile, S. Giordano, J. A. López-Sáez, and R. C. Cobianchi, "Antibacterial activity of pure flavonoids isolated from mosses," Phytochemistry, vol. 52, no. 8, pp. 1479-1482, 1999.

[163] C. S. A. Lima, E. L. C. de Amorim, K. R. de Sena et al., "Antimicrobial activity of a mixture of two isomeric phenylpropanoid glycosides from Arrabidaea harleyi A. H. Gentry (Bignoniaceae)," Brazilian Journal of Pharmaceutical Sciences, vol. 39, no. 1, pp. 77-81, 2003.

[164] K. Ono, H. Nakane, M. Fukushima, J. C. Chermann, and F. Barré-Sinoussi, "Differential inhibitory effects of various flavonoids on the activities of reverse transcriptase and cellular DNA and RNA polymerases," European Journal of Biochemistry, vol. 190, no. 3, pp. 469-476, 1990.

[165] A. J. Vlietinck, T. de Bruyne, S. Apers, and L. A. Pieters, "Plant-derived leading compounds for chemotherapy of human immunodeficiency virus (HIV) infection," Planta Medica, vol. 64, no. 2, pp. 97-109, 1998.

[166] M. Martinez-Velazquez, R. Rosario-Cruz, G. Castillo-Herrera, J. M. Flores-Fernandez, A. H. Alvarez, and E. Lugo-Cervantes, "Acaricidal effect of essential oils from Lippia graveolens (Lamiales: Verbenaceae), Rosmarinus officinalis (Lamiales: Lamiaceae), and Allium sativum (Liliales: Liliaceae) against Rhipicephalus (Boophilus) microplus (Acari: Ixodidae)," Journal of Medical Entomology, vol. 48, no. 4, pp. 822-827, 2011.

[167] B.-E. van Wyk, F. van Heerden, and B. van Oudtshoorn, Poisonous Plants of South Africa, Briza Publications, Pretoria, South Africa, 2009. 
[168] T. Heikel, B. C. Knight, C. Rimington, H. D. Ritchie, and E. J. Williams, "Studies on biliary excretion in the rabbit. 1: the effect of icterogenin and rehmannic acid on bile flow and the excretion of bilirubin, phylloerythrin, coproporphyrin, alkaline phosphatise and bromosulfalein," Proceedings of the Royay Society of London: Series B, Biological Sciences, vol. 153, no. 950, pp. 47-79, 1960.

[169] D. A. Mpofu, U. Marume, V. Mlambo, and A. Hugo, "The effects of Lippia javanica dietary inclusion on growth performance, carcass characteristics and fatty acid profiles of broiler chickens," Animal Nutrition, vol. 2, no. 3, pp. 160-167, 2016.

[170] V. L. Williams, K. Balkwill, and E. T. F. Witkowski, "A lexicon of plants traded in the Witwatersrand umuthi shops, South Africa," Bothalia, vol. 31, no. 1, pp. 71-98, 2001.

[171] D. Raimondo, L. von Staden, W. Foden et al., Red List of South African Plants, Strelitzia 25, South African National Biodiversity Institute, Pretoria, South Africa, 2009. 


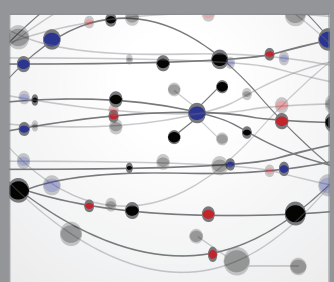

The Scientific World Journal
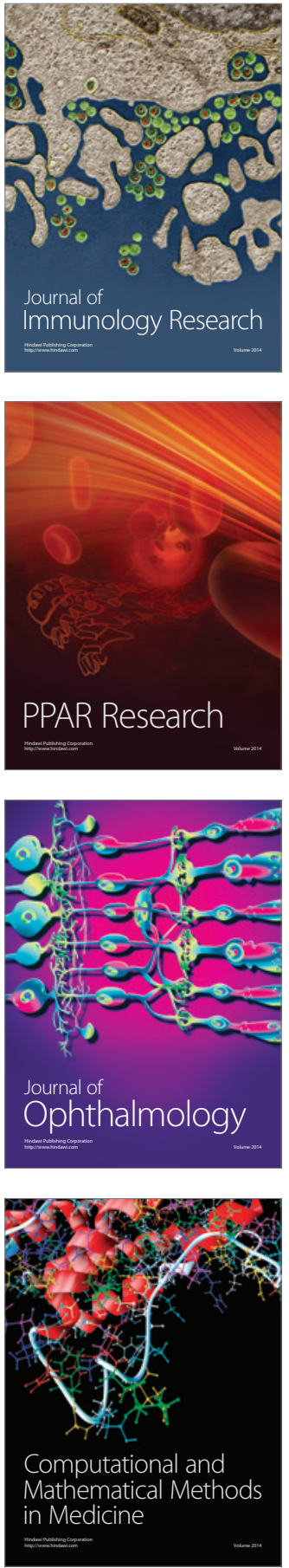

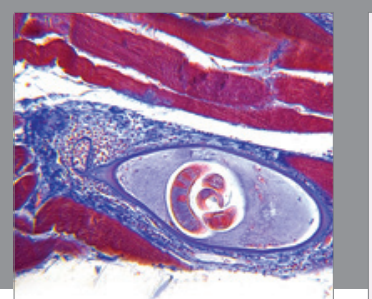

Gastroenterology Research and Practice
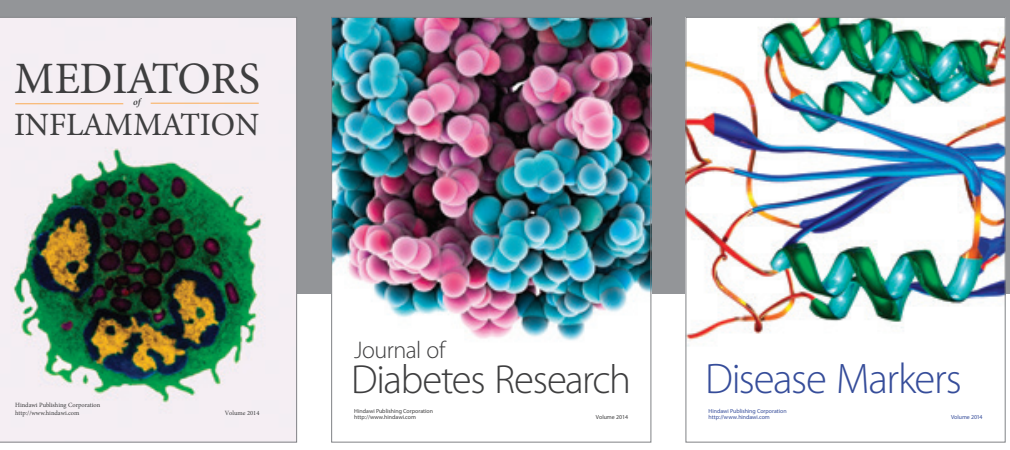

Disease Markers

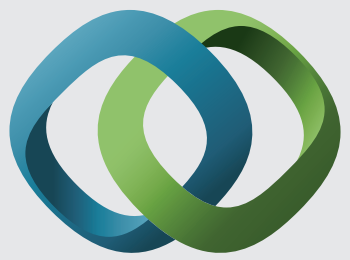

\section{Hindawi}

Submit your manuscripts at

https://www.hindawi.com
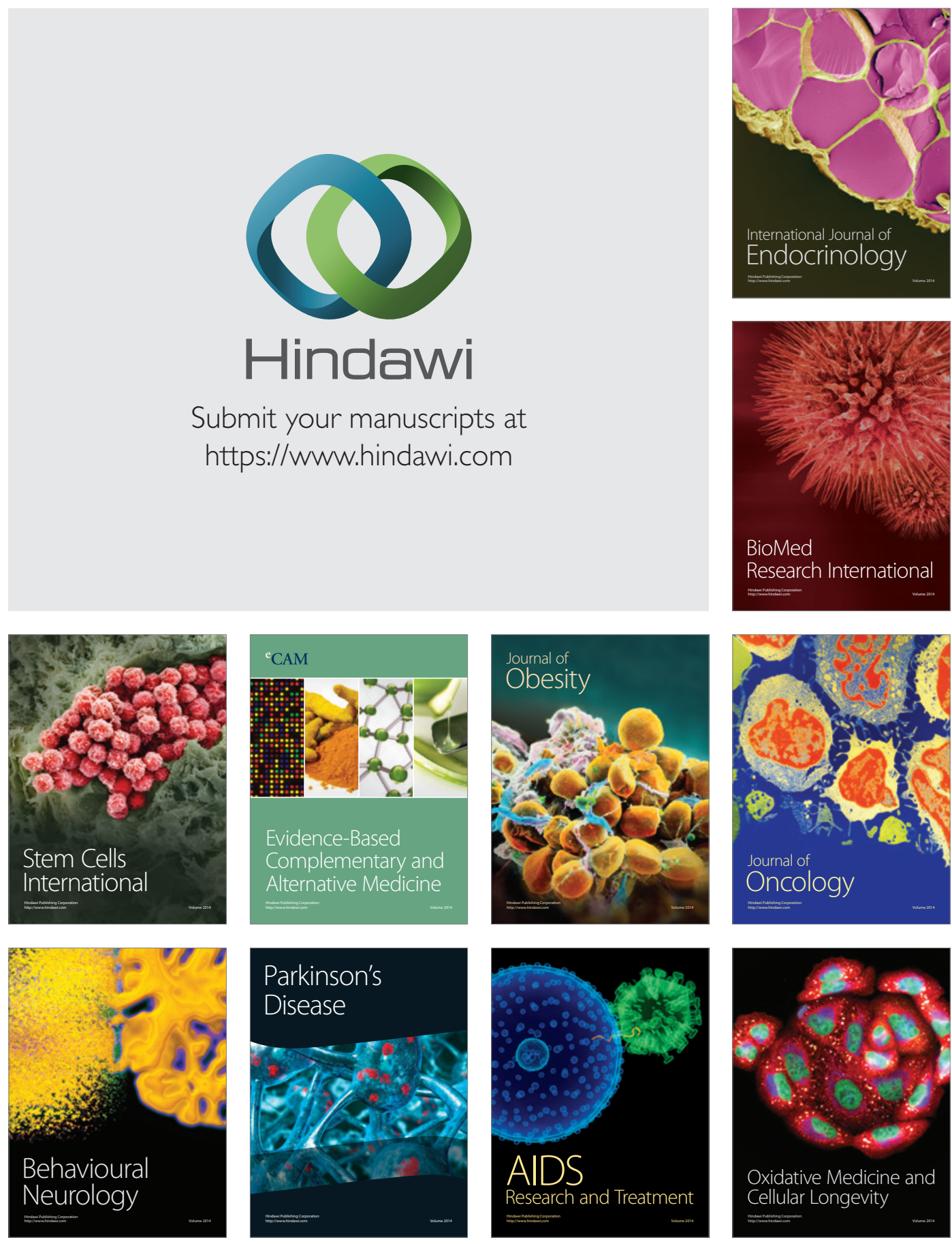